\title{
1 Forest growth responds more to air pollution than soil acidification
}

2

3 Jakub Hruška ${ }^{1,2 q *}$, Filip Oulehle ${ }^{1,2 q}$, Tomáš Chuman ${ }^{1,2 \&}$, Tomáš Kolářr2,3ף, Michal Rybníček ${ }^{2,3 \&}$

4 and William H. McDowell ${ }^{4 \&}$

$6{ }^{1}$ Global Change Research Institute, Czech Academy of Sciences, Bělidla 986/4a, 60300 Brno,

$7 \quad$ Czech Republic

8

${ }^{2}$ Czech Geological Survey, Klárov 3, 118 21, Praha 1, Czech Republic

9

Mendel University in Brno, Zemědělská 3, Brno, 613 00, Czech Republic

${ }^{4}$ Department of Natural Resources and the Environment, University of New Hampshire,

Durham, 03824, NH, United States

E-mail: jakub.hruska@geology.cz

17 TThese authors contributed equally to this work.

\&These authors also contributed equally to this work. 


\section{Abstract}

The forests of central Europe have undergone remarkable transitions in the past 40 years as air quality has improved dramatically. Retrospective analysis of Norway spruce (Picea abies) tree rings in the Czech Republic shows that air pollution (e.g. $\mathrm{SO}_{2}$ concentrations, high acidic deposition to the forest canopy) plays a dominant role in driving forest health. Extensive soil acidification occurred in the highly polluted "Black Triangle" in Central Europe, and upper mineral soils are still acidified. In contrast, acidic atmospheric deposition declined by $80 \%$ and atmospheric $\mathrm{SO}_{2}$ concentration by $90 \%$ between the late 1980 s and 2010 s. Annual tree ring width (TRW) declined in the 1970s and subsequently recovered in the 1990s, tracking $\mathrm{SO}_{2}$ concentrations closely. Furthermore, recovery of TRW was similar in unlimed and limed stands. Despite large increases in soil base saturation, as well as soil $\mathrm{pH}$, as a result of repeated liming starting in 1981, TRW growth was similar in limed and unlimed plots. TRW recovery was interrupted in 1996 when highly acidic rim (originating from more pronounced decline of alkaline dust than $\mathrm{SO}_{2}$ from local power plants) injured the spruce canopy, but recovered soon to the pre-episode growth. Across the long-term site history, changes in soil chemistry $(\mathrm{pH}$, base saturation, $\mathrm{Bc} / \mathrm{Al}$ soil solution ratio) cannot explain observed changes in TRW at the two study sites at which we tracked soil chemistry. Instead, statistically significant recovery in TRW is linked to the trajectory of annual $\mathrm{SO}_{2}$ concentrations or sulfur deposition at all three stands.

\section{Introduction}

Central Europe was heavily polluted by $\mathrm{SO}_{2}$ originating from burning high sulfur lignite for electricity generation $[1,2]$. In the so-called "Black Triangle" region on the border of Germany (former DDR), Poland and the Czech Republic (former Czechoslovakia), massive 
forest dieback occurred starting in the 1960s with a peak in the 1970s and 1980s. In the

Czech Republic alone, 1.5 million ha of forest were heavily damaged and about 40000 ha of mainly Norway spruce (Picea abies) stands died or were salvaged logged due to air pollution [3], which represents ca. 9.5 million cubic meters of wood [2]. The decline in $\mathrm{SO}_{2}$ emission during the 1990s was one of the great "success stories" in environmental protection worldwide [4, 5]. Czech $\mathrm{SO}_{2}$ emissions declined from $3150 \mathrm{Mkg}$ of $\mathrm{SO}_{2}$ to $86.6 \mathrm{Mkg}$ in 2017 [2], representing a decline of more than $97 \%$. Annual ambient $\mathrm{SO}_{2}$ concentration in the Czech part of the Black Triangle has declined from up to $130 \mu \mathrm{g} \cdot \mathrm{m}^{-3}$ measured in the $1970 \mathrm{~s}$ to less than $10 \mu \mathrm{g} \cdot \mathrm{m}^{-3}$ at present [2]. The estimated median total deposition of $\mathrm{S}$ in the current Czech Republic peaked in $1979\left(41 \mathrm{~kg} \mathrm{~S} \mathrm{ha}^{-1} \cdot \mathrm{yr}^{-1}\right)$ and then declined to $7.3 \mathrm{~kg} \mathrm{~S} \mathrm{ha}^{-1} \cdot \mathrm{yr}^{-1}$ in 2012 [6]. Recent estimates show that S deposition had fallen even further by $2017\left(5.4 \mathrm{~kg} \mathrm{~S} \mathrm{ha}^{-1} \cdot \mathrm{yr}^{-1}\right)$.

Acid deposition results in elevated inorganic $\mathrm{Al}$ and $\mathrm{H}^{+}$in soil solution, especially in soils with low base saturation $(<20 \%)$. For forests, where the toxicity of aluminium to tree roots is considered to be critical, the $\mathrm{Al}^{3+}$ to $\mathrm{Ca}^{2+}$ ratio in soil water has become the main driver of damage to roots $[7,8]$ or crown defoliation and transformation. High inorganic Al in soil solution can also impact tree fine root growth and functioning [9].

Foliar injury by air pollutants has also been identified as a reason for forest dieback in highly polluted areas such as the Black Triangle [10], and high concentrations of $\mathrm{SO}_{2}$ and ozone result in canopy decline [11]. Deterioration of cuticular waxes and leaching of nutrients from the canopy [12] leading to chlorosis and decline of photosynthesis is thought to drive the canopy decline and contribute to forest dieback. Widespread and quick declines of Norway spruce in the Black Triangle in the 1970s were usually also connected with climatic episodes when highly acidic fog or rim during winter inversions seriously damaged spruce canopy [1]. 
One of the best opportunities for evaluating the future capacity of individual species is a retrospective analysis of past growth responses to climate and pollution [13, 14]. Highresolution long-term proxies, where annual changes can be delineated, are needed for describing previous environmental variability [15]. Annual rings produced by temperate tree species provide a retrospective record of tree growth in response to past environmental conditions $[16,17,18]$.

In this paper, we examined the growth response of Norway spruce (Picea abies) to (i) longterm air pollution by $\mathrm{SO}_{2}$ (ii); acidic deposition; and (iii) soil chemistry in the formerly extremely $\mathrm{SO}_{2}$-polluted Ore Mts. in the northern Czech Republic, to determine the most important factors affecting forest vitality during the past 50 years.

\section{Site description}

The study sites are spruce stands located in the Ore Mountains (Krušné hory in Czech, Erzgebirge in German), northwestern Czech Republic (Fig. 1). All Norway spruce (Picea abies) stands are at a similar altitude (Tab. 1) and are exposed to similar climatic conditions. The average annual temperature in the region is $7.1^{\circ} \mathrm{C}$, and the average annual precipitation is $1110 \mathrm{~mm}(2005-2017)$.

The Načetín experimental forest stand has been studied since the late 1980s as part of research into the phenomenon of acid rain $[19,20,21]$. Experimental liming by 3 tons per hectare of dolomitic limestone occurred in an experimental plot of Načetín site in 2007, thus "Načetín control" and "Načetín liming" will be used to identify different subplots.

Table I. Characteristics of studied plots in Ore Mts., Czech Republic. 


\begin{tabular}{|c|c|c|c|c|c|c|}
\hline Site & Coordinates & Bedrock & Soil & $\begin{array}{l}\text { Altitude } \\
\text { (m a.s.l.) }\end{array}$ & $\begin{array}{l}\text { Forest age } \\
\text { (years) }^{*}\end{array}$ & $\begin{array}{l}\text { Liming (year, } \\
\text { dose in tons. ha-1) }\end{array}$ \\
\hline Načetín & $\begin{array}{l}50^{\circ} 33^{\prime} 23^{\prime \prime} \\
13^{\circ} 15^{\prime} 12^{\prime \prime}\end{array}$ & Gneiss & $\begin{array}{l}\text { Dystric } \\
\text { cambisol }\end{array}$ & 775 & 95 & $2007 * *, 3.0$ \\
\hline Kovářská & $\begin{array}{l}50^{\circ} 29^{\prime} 53^{\prime \prime} \\
13^{\circ} 07^{\prime} 20^{\prime \prime}\end{array}$ & Gneiss & $\begin{array}{l}\text { Dystric } \\
\text { cambisol }\end{array}$ & 786 & 116 & $\begin{array}{l}1981,1.5 \\
1988,2.0 \\
1997,3.0\end{array}$ \\
\hline $\begin{array}{l}\text { Černý } \\
\text { potok }\end{array}$ & $\begin{array}{l}50^{\circ} 28^{\prime} 09^{\prime \prime} \\
13^{\circ} 03^{\prime} 54^{\prime \prime}\end{array}$ & Gneiss & $\begin{array}{l}\text { Dystric } \\
\text { cambisol }\end{array}$ & 768 & 69 & $\begin{array}{l}1981,1.5 \\
1988,2.0 \\
1997,3.0\end{array}$ \\
\hline Fláje & $\begin{array}{l}50^{\circ} 40^{\prime} 48^{\prime \prime} \\
13^{\circ} 34^{\prime} 12^{\prime \prime}\end{array}$ & Basalt & Ranker & 860 & 69 & $\begin{array}{l}1981,1.5 \\
1988,2.0 \\
1997,3.0\end{array}$ \\
\hline
\end{tabular}

*first identified tree ring +10 years

**Načetín limed only

Tree rings were sampled at each plot, although soil chemistry was not analysed at Černý potok as the site position, bedrock, and soils were almost identical with the nearby Kovářská site.

Figure 1. Study site locations in Ore Mts., Czech Republic.

\section{Methods}

3.1. Tree-ring sampling and chronology development 
98

99

100

101

102

103

104

105

106

107

108

109

110

111

112

113

We randomly sampled 15 spruce trees at each forest site. Considering the lack of directionspecific effects on variability in tree radial growth [22], one core per tree was extracted using a Pressler borer (Haglof Company Group) at breast height (1.3 m). To avoid compression wood, the cores were sampled in a direction parallel to the slope. All samples were measured using a VIAS TimeTable device with a measuring length of $78 \mathrm{~cm}$ and resolution $<1 / 100 \mathrm{~mm}$ (CSCIEM, Vienna, Austria). The TRW series were measured (accuracy of 0.01 $\mathrm{mm}$ ) and cross-dated using PAST4 [23]. Missing and false rings were corrected using both PAST4 [23] and COFECHA [24].

To remove non-climatic, age-related growth trends from the raw tree ring width (TRW) series as well as other non-climatic factors (e.g., competition), we applied cubic smoothing splines with a 50\% frequency cutoff at 100 years [25] using ARSTAN software [26]. We used this method to preserve interannual to multi-decadal growth variations [27]. TRW indices were calculated as residuals after applying an adaptive power transformation to the raw measurement series [28]. The site chronologies were calculated using bi-weight robust means. Similarities among the site TRW chronologies were assessed using statistical criteria (correlation coefficient; Gleichläufigkeit [29]) and visual comparison. Negative extremes were defined by years in which the standardised TRW chronology (period replicated $>20$ TRWi series) exceeded the -1.0 multiple of a standard deviation (SD).

Soils were sampled in 2018 by excavating four $0.5 \mathrm{~m}^{2}$ quantitative pits using the method described by Huntington et al. [30]. The $\mathrm{O}_{\mathrm{I}}\left(\right.$ litter) and $\mathrm{O}_{\mathrm{f}}+\mathrm{O}_{\mathrm{h}}$ (fermented + humified) horizons 

organic horizons and $2 \mathrm{~mm}$ for mineral horizons). Soil moisture was determined in a water extract. Exchangeable cations were analysed in $0.1 \mathrm{M} \mathrm{BaCl}_{2}$ extracts by the flame atomic absorption spectrometry (FAAS). Cation exchange capacity (CEC) was calculated as Načetín was sampled monthly since 1994 using quartz and Teflon suction lysimeters (Prenart) from the depth of $-30 \mathrm{~cm}$ of mineral soil.

\subsection{MAGIC model}

MAGIC (Model of Acidification of Groundwater in Catchments) was designed to reconstruct past and predict future drainage water and soil chemistry [31, 32, 33]. MAGIC is a lumpedparameter model of intermediate complexity which calculates for annual time steps the concentration of major ions under the assumption of simultaneous reactions involving $\mathrm{SO}_{4}$ adsorption, cation exchange, dissolution-precipitation-speciation of aluminium and dissolution-speciation of inorganic and organic C. MAGIC accounts for the mass balance of major ions in the soil by bookkeeping the fluxes from atmospheric inputs, chemical weathering, net uptake in biomass and loss to runoff. Water fluxes, wet and dry atmospheric deposition, net vegetation uptake, weathering, and a description of organic acids are 


\section{Results and Discussion}

147

148

149

150

151

152

153

154

155

156

157

158

159

160

161

162

163

164

165

166

167

168

4.1. Atmospheric chemistry and deposition

Historically, sulfur emission and deposition were associated with mining and burning brown coal (lignite) from the nearby Bohemian coal basin (Fig. 2) since the second half of the $19^{\text {th }}$ century. The period after World War II was accompanied by a massive production of energy by burning this high $\mathrm{S}$ content lignite in the local power plants. Coal mining, as well as $\mathrm{SO}_{2}$ emissions (Fig. 3), peaked in the 1980s. The decrease since then can be attributed in part to the declining volume of coal mined after 1989, when the extensive industrial activity in former Czechoslovakia declined with a change in political structure. Coal mining declined from its peak in 1982 (130 Mt) to $58 \mathrm{Mt}$ in 2017 [2].

\section{Figure 2. Coal mining and dust emissions in the Czech Republic between 1850-2017.}

There was a distinct break in $\mathrm{SO}_{2}$ emissions in 1993 when the first power plants in the Czech

Republic were equipped with flu-gas desulfurisation (Fig. 3). This process was completed in 1999. As a result, $\mathrm{SO}_{2}$ emissions declined from a peak of $395 \mathrm{mmol} \cdot \mathrm{m}^{-2} \cdot \mathrm{yr}^{-2}$ in 1982 to 25 $\mathrm{mmol} \cdot \mathrm{m}^{-2} \cdot \mathrm{yr}^{-2}$ in 1999. Since then, it fell to $10 \mathrm{mmol} \cdot \mathrm{m}^{-2} \cdot \mathrm{yr}^{-2}$ in 2017 (Fig. 3) due to the continuous decline in coal mining (Fig. 2). Modelled S emissions coincide very well with measured ambient $\mathrm{SO}_{2}$ concentrations. The longest record in the region is available from Zinwald station [34] on the Czech-German border on the ridge of the Ore Mts. (Fig. 1). Annual concentrations peaked in the mid-1980s at $93 \mu \mathrm{g} \cdot \mathrm{m}^{-3}$ (Fig. 3). As $\mathrm{SO}_{2}$ emissions 

[36].

declined, ambient $\mathrm{SO}_{2}$ concentrations declined proportionally to ca. $10 \mu \mathrm{g} \cdot \mathrm{m}^{-3}$ in the late 1990s and $4 \mu \mathrm{g} \cdot \mathrm{m}^{-3}$ in 2017.

Figure 3. $\mathrm{SO}_{2}$ emissions (Czech Republic) between 1850-2017 and ambient annual $\mathrm{SO}_{2}$ concentrations measured at Cínovec (Zinwald) at the Czech/German border between 1979-2017.

Dust emissions (Fig. 2) increased similarly to coal mining activities [6]. Dust was rich in base cations (primarily Ca) and partly neutralised precipitation acidity (Fig. 4). Despite this neutralisation, precipitation pH was about 4.2 during the 1970s and 1980s [35] (Fig. 4) and has risen slowly since the 1990 s to values $>5.0$ in recent years. Electrostatic removal of dust from power plants started in the 1980s when it peaked at around $12 \mathrm{~g} \cdot \mathrm{m}^{-2}$. It declined sharply to $<1 \mathrm{~g} \cdot \mathrm{m}^{-2}$ until the late $1990 \mathrm{~s}$ (Fig. 2). As dust removal was effective earlier than $\mathrm{SO}_{2}$ removal (Fig. 3), the ratio of $\mathrm{SO}_{2}$ /dust in the atmosphere peaked in the 1990s (Fig. 4). This peak in $\mathrm{SO}_{2}$ /dust was accompanied by highly acidic episodes like the formation of acidic rime ice in the winter of $1995 / 1996$. The acidity of the rime developed on the spruce canopy at Načetín was measured to be $\mathrm{pH}<3$ (lowest $\mathrm{pH}=2.33$ was recorded in January/February 1996). Ambient $\mathrm{SO}_{2}$ concentration was $2300 \mu \mathrm{g} \cdot \mathrm{m}^{-3}$ at Rudolice, $20 \mathrm{~km}$ east of Načetín (February $2^{\text {nd }} 1996$ ) as a result of repeated inversions occurring on the ridge of the Ore Mts. 
191

192

193

194

195

196

197

198

199

200

201

202

203

204

205

206

207

208

Figure 4. Modelled and measured annual precipitation $\mathrm{pH}$ and $\mathrm{SO}_{2} /$ dust ratio (1850-2017) for the Czech Republic. Modelled values from 1850 to 2013 for pH, 1850 to 2013 for $\mathrm{SO}_{2}$ /dust ratio.

Based on the coal mining and measured sulfur deposition data between the 1990s and 2010s from the Czech Republic, Germany and Poland [6], constructed a simple statistical model for reconstructing and predicting historic $\mathrm{S}$ deposition. This model estimated the deposition of S in throughfall for sites in the Ore Mts (Fig. 5) for the period 1850-2017. All sites showed synchronous patterns, with the highest deposition estimated for Fláje (ca. 550 meq $\cdot \mathrm{m}^{-2} \cdot \mathrm{yr}^{-1}$ in the 1980s), but other sites (Kovářská and Načetín) also received very high loads (ca. $\left.480 \mathrm{meq} \cdot \mathrm{m}^{-2} \cdot \mathrm{yr}^{-1}\right)$. Present deposition $\left(60-70 \mathrm{meq} \cdot \mathrm{m}^{-2} \cdot \mathrm{yr}^{-1}\right)$ is equal to the historical values estimated for the second half of the $19^{\text {th }}$ century and representing an $80-90 \%$ decline (Fig. 5).

Figure 5. Modelled (1850-1993) and measured (1994-2017) annual sulfur deposition at study sites in the Ore Mts.

\subsection{Soil chemistry}

4.2.1. Long-term changes at Načetín.

Since 1994, four soil sampling campaigns were undertaken at the Načetín control site.

Despite a significant decrease in atmospheric deposition of sulfur (Fig. 5), soil chemistry 
exhibited only limited changes. Soil base saturation (BS) has increased only in the organic layer between 1994 and 2003 and has stayed at a similar level of 33-37\% since 2003 (Fig. 6). Mineral soil BS did not change significantly between 1994 and 2008, but declined in 2018 to the lowest measured levels, with values of only $3 \%$ of saturation at a depth of $20-40 \mathrm{~cm}$ compared to the initial value of $6 \%$ at that depth in 1994 (Fig. 6). Total exchangeable acidity (TEA) declined significantly in the humus horizon (from $125 \mathrm{mmol}_{\mathrm{c}^{\cdot}} \mathrm{kg}^{-1}$ in 1994 to 67 $\mathrm{mmol} \cdot \mathrm{kg}^{-1}$ in 2018). It decreased markedly in the upper mineral soil $(0-10 \mathrm{~cm})$ but did not change in deeper mineral soil (Fig. 6). Soil pH did not exhibit consistent trends over time and increased from 3.6 in the forest floor up to 4.4 in the B horizon $(20-40 \mathrm{~cm})$. Exchangeable calcium has declined similarly to TEA, with significant declines in the humus horizon (from $600-700 \mathrm{mg} \cdot \mathrm{kg}^{-1}$ in 1994 to about 450 in 2018) and in the upper mineral soil (from 70 to 15 $\left.\mathrm{mg} \cdot \mathrm{kg}^{-1}\right)$. Similar sharp declines were observed in deeper mineral horizons, with exchangeable Ca dropping from about 30 to $7 \mathrm{mg} \cdot \mathrm{kg}^{-1}$ at $10-20 \mathrm{~cm}$ and from 20 to $4 \mathrm{mg} \cdot \mathrm{kg}^{-1}$ at $20-30 \mathrm{~cm}$ (Fig. 6). Patterns for exchangeable Mg were similar to those of Ca (data not shown).

\section{Figure 6. Long-term changes of soil chemistry at the Načetín control research site (1994-} 2018).

\subsubsection{Variation in soil chemistry among sites}

Among our study sites, the most acidic was the Načetín control plot (exchangeable $\mathrm{pH}=3.4$ at FH horizon) followed by Načetín limed plot, Kovářská and Fláje (4.7 at FH horizon, Fig. 7). 
Soil $\mathrm{pH}$ showed the typical pattern being most acidic in the organic $\mathrm{FH}$ horizons and the highest exchangeable $\mathrm{pH}$ was observed in the deeper mineral soil. Soil base saturation has declined at all sites from $L$ horizon down to mineral $20-40 \mathrm{~cm}$. The lowest BS was observed for the Načetín control plot $(70 \%$ in L horizon and $3 \%$ in $20-40 \mathrm{~cm})$ and highest at Fláje (95\% in $L$ and $39 \%$ in $20-40 \mathrm{~cm}$ respectively).

\section{Figure 7. Soil pH and base saturation in 2018.}

Soil base saturation follows liming history as well as geological settings. The second most acidic site (Načetín limed, underlined by gneiss) was experimentally limed in 2007 (Table I). Other sites Kovářská (gneiss) and Fláje (basalt) were limed three times (Table I) between 1981 and $1997[37,38]$ by a cumulative dose of 6.5 t.ha-1. As a result, soil pools of Ca were 8x higher, and the Mg pool was 11x enriched (Table 2) at Kovárská, even though it is underlain by similar bedrock (gneiss) as Načetín. Similar levels of enrichment were observed at Fláje, which is underlain by basalt. As Načetín was limed in 2007 by a lower dose ( $\left.3 \mathrm{t} \cdot h \mathrm{~h}^{-1}\right)$, Ca enrichment was only $3 x$ and $M g$ 4x (Tab. 2), reflecting slow kinetics of the limestone dissolution (S1 Annex).

\subsubsection{Estimate of historical soil chemistry development}

As tree rings reflected forest damage and the physiological stress in the past, retrospective soil chemistry development was needed for disentangling the effects of ambient air chemistry, atmospheric deposition and soil chemistry on tree growth. According to the MAGIC model estimates (S1 Annex), soil base saturation declined during the $19^{\text {th }}$ and most 
of the $20^{\text {th }}$ century due to increasing acidic deposition (Fig. 5) at all of our study sites (Fig. 8),

258

259

260

261

262

263

indicating an ongoing depletion of the soil pool of exchangeable base cations. At Načetín control, where liming was not applied, the MAGIC simulations showed significant depletion, from an estimated base saturation of $19 \%$ in 1850 to $6 \%$ in 2018 . The projected recovery, with acid deposition assumed to be unchanged from levels in 2018, revealed only minor improvements of soil base saturation (7\% in 2050). This indicates a balance between base cations inputs (weathering + deposition) and outputs (uptake + leaching) for future decades. Other limed sites exhibited similar patterns until liming when base saturation increased significantly (Fig. 8). Načetín limed revealed now BS of $16.5 \%$, not far from the preindustrial estimate (19\%). Future scenarios predict base saturation of $27 \%$ in 2050 . A more pronounced liming effect was observed and modelled for Kovářská where the preindustrial estimate was $19 \%$ but measured BS was $38.5 \%$ in 2018 . This high base saturation was due to earlier liming (beginning in 1981) and a higher cumulative dose (Table I). More alkaline bedrock with a high weathering rate (see S1 Annex) at Fláje resulted in preindustrial base saturation of $45 \%$ (Fig. 8). Acid deposition lowered BS to $15 \%$ in 1981 and subsequent liming raised $\mathrm{BS}$ to $64 \%$ in 2018 , significantly higher than the preindustrial estimate.

Figure 8. Modelled and measured (a) soil base saturation, (b) soil solution pH and (c) soil solution Bc/Al ratio (1850-2050) for all investigated sites.

Preindustrial soil water $\mathrm{pH}$ was estimated to be 4.7 (Fig. 8) at Načetín, and the lowest pH (4.25) was modelled for the 1980s. pH started to rise soon after the decline in deposition in the 1990 s (Fig. 5). A pH of 4.45 was reached at the naturally regenerated control plot by 2018 (Table II). The limed plot's pH increased to 4.55 between 2007 and 2018. Modelled was 

measured and modelled $\mathrm{pH}$ of 4.65 in 2018 and an estimated $\mathrm{pH}$ of 4.8 in 2050. Highly was higher than the preindustrial estimate.

The molar $\mathrm{Bc} / \mathrm{Al}$ ratio $((\mathrm{Ca}+\mathrm{Mg}+\mathrm{K}) / \mathrm{Al})$ in soil solution was estimated to be around two as a preindustrial value (Fig. 8) and it declined to as low as 0.2 in the $1980 \mathrm{~s}$. In contrast to $\mathrm{pH}$, it increased significantly to 1.5 in 2018 and future predictions are that $\mathrm{Bc} / \mathrm{Al}$ will rise to 3.5 in minimum of 0.2 for the beginning of the 1980 s, 8.0 for 2018 and 13 for 2050 .

Table II. Pools of base cations, carbon and nitrogen measured in 2018.

\begin{tabular}{|c|c|c|c|c|c|c|c|c|c|c|c|c|c|c|c|c|c|c|c|c|c|}
\hline \multirow[t]{2}{*}{ Site } & \multirow[t]{2}{*}{ Soil horizon } & Fine earth & $\mathrm{pH}(\mathrm{H} 2 \mathrm{O})$ & $\mathrm{pH}(\mathrm{KCl})$ & Ca & \multicolumn{2}{|c|}{$\mathrm{Mg}$} & \multicolumn{2}{|c|}{$\mathrm{Na}$} & \multicolumn{2}{|r|}{$\mathrm{k}$} & \multicolumn{3}{|c|}{$\begin{array}{l}\text { exchangeable exchangeable } \\
\text { acidity } \mathrm{Al}+\mathrm{H} \quad \mathrm{Al}\end{array}$} & $\begin{array}{c}\text { cation } \\
\text { exchange } \\
\text { capacity (CEC) }\end{array}$ & $\begin{array}{c}\text { Sum of base } \\
\text { cations }\end{array}$ & Base saturation & \multicolumn{2}{|r|}{ c } & $\mathrm{N}$ & \\
\hline & & $\mathrm{kg} / \mathrm{m}^{2}$ & & & & & $\mathrm{mg} /$ & & & & & & & $\mathrm{mmo}$ & $\mathrm{ol} / \mathrm{kg}$ & & & & $\%$ & & $\mathrm{~g} / \mathrm{g}$ \\
\hline Načetín - control & $L$ & $2.1 \pm 1.0$ & $3.97 \pm 0.2$ & $3.11 \pm 0.2$ & $572 \pm 180$ & $99 \pm$ & 16 & 8.6 & \pm 3.3 & 317 & \pm 79 & $19 \pm 4.4 \quad 0$ & $0.10 \pm$ & \pm 0.0 & $64 \pm 7.8$ & $45 \pm 8.8$ & $70 \% \pm 7.2 \%$ & $47 \%$ & $\pm 0.8 \%$ & $1.6 \% \pm 0.1 \%$ & $29 \pm 2.9$ \\
\hline Načetín - control & $\mathrm{FH}$ & & & $2.43 \pm 0.1$ & $315 \pm 141$ & & \pm 11 & & \pm 2.8 & 124 & & $77 \pm 6.2$ & & \pm 5.0 & $104 \pm 9.7$ & & $26 \% \pm 5.9 \%$ & $36 \%$ & $\pm 2.5 \%$ & $1.7 \% \pm 0.1 \%$ & \\
\hline Načetín - control & $0-10$ & $54 \pm 7.0$ & $3.65 \pm 0.1$ & $2.83 \pm 0.1$ & $16 \pm 7.3$ & $16 \pm$ & \pm 7.6 & 5.2 & \pm 0.6 & 25 & \pm 5.2 & $66 \pm 4.3$ & $42 \pm$ & \pm 5.2 & $69 \pm 4.2$ & $3.0 \pm 1.1$ & $4.3 \%$ & $8.4 \%$ & $0.6 \%$ & $0.4 \%$ & 0.1 \\
\hline Načetín - control & & $51 \pm 6.5$ & $3.99 \pm 0.2$ & $3.29 \pm 0.2$ & $7.4 \pm 1.9$ & $8.0 \pm$ & \pm 3.2 & 4.4 & \pm 0.6 & 14 & \pm 3.8 & $67 \pm 9.9$ & $42 \pm$ & \pm 6.6 & $69 \pm 10$ & $1.6 \pm 0.4$ & $2.3 \%=$ & $4.5 \%$ & $0.7 \%$ & $\pm 0.03 \%$ & \\
\hline & $20-40$ & $103 \pm 14.0$ & $4.43 \pm 0.1$ & $3.90 \pm 0.1$ & $4.4 \pm 0.7$ & $1.7 \pm$ & 0.5 & 3.2 & & 7.2 & \pm 2.4 & $27 \pm 7.0$ & & \pm 4.9 & $28 \pm 7.2$ & $0.7 \pm 0.2$ & $2.5 \% \pm 0.2 \%$ & $2.8 \%$ & $\pm 0.3 \%$ & $0.1 \% \pm 0.02 \%$ & \\
\hline Soil mean/sum & & $219 \pm 1.9$ & $4.09 \pm 0.093$. & $3.43 \pm 0.10$ & $26 \pm 12$ & $11 \pm$ & 4.6 & 4.5 & \pm 0.8 & 21 & \pm 3.5 & $48 \pm 3.5$ & $30 \pm$ & \pm 2.9 & $51 \pm 3.5$ & $2.9 \pm 1.0$ & $5.8 \% \pm 1.9 \%$ & $6.3 \%$ & $\pm 0.3 \%$ & $0.30 \% \pm 0.01 \%$ & $20 \pm 1.0$ \\
\hline Načetín - limed & $\mathrm{L}$ & $1.8 \pm 0.7$ & $4.50 \pm 0.4 \quad 3$. & $3.35 \pm 0.2 \quad 10$ & $1076 \pm 181$ & $205 \pm$ & & 11 & \pm 2.3 & 379 & \pm 57 & $13 \pm 1.9 \quad 0$ & $0.10 \pm$ & \pm 0.0 & $94 \pm 11$ & $81 \pm 12$ & $86 \% \pm 3.1 \%$ & $46 \%$ & $\pm 0.6 \%$ & $1.7 \% \pm 0.1 \%$ & $28 \pm 2.0$ \\
\hline Načetín - limed & $\mathrm{FH}$ & $8.3 \pm 1.0$ & $3.68 \pm 0.3$ & $2.79 \pm 0.3$ & $1117 \pm 553$ & $322 \pm$ & \pm 176 & 11 & \pm 6.8 & 113 & \pm 58 & $36 \pm 12$ & & \pm 6.9 & $121 \pm 27$ & & $67 \% \pm 21 \%$ & $39 \%$ & $\pm 1.9 \%$ & $1.8 \% \pm 0.03 \%$ & \\
\hline čtetin -limed & $0-10$ & $54 \pm 7.0$ & $3.76 \pm 0.1$ & $2.90 \pm 0.1$ & $48 \pm 24$ & $92 \pm$ & \pm 46 & 8.1 & \pm 0.5 & & \pm 7.8 & $70 \pm 3.1$ & & \pm 4.6 & $81 \pm 7.2$ & & $14 \% \pm 5.5 \%$ & $10 \%$ & $\pm 1.7 \%$ & $0.4 \% \pm 0.06 \%$ & \\
\hline Načetín - limed & $10-20$ & $51 \pm 6.5$ & $4.16 \pm 0.3$ & $3.45 \pm 0.3$ & $9.3 \pm 2.4$ & $30 \pm$ & \pm 17 & 5.3 & \pm 0.6 & & \pm 3.9 & $48 \pm 14$ & & \pm 8.9 & $52 \pm 14$ & $3.6 \pm 1.4$ & & $4 \%$ & $\pm 1.6 \%$ & $0.2 \% \pm 0.06 \%$ & $22 \pm 2.8$ \\
\hline$\frac{\text { Načetín - limed }}{S \text { Soilman }}$ & $20-40$ & $\frac{103 \pm 14.0}{218 \pm 11}$ & $4.40 \pm 0.2$ & $\frac{3.92 \pm 0.2}{3.51 \pm 0.07}$ & $\begin{array}{l}5.0 \pm 2.1 \\
69+29\end{array}$ & $\frac{5.4 \pm}{46 \pm t}$ & \pm 2.2 & $\frac{4.1}{57}$ & \pm 0.7 & $\frac{8.7}{24}$ & \pm 3.0 & $\frac{23 \pm 12}{41 \pm 86}$ & $\frac{19 \pm}{30 . \pm}$ & \pm 12 & $\frac{25 \pm 12}{49+65}$ & $\frac{1.1 \pm 0.2}{81 \pm 30}$ & $5 \% \pm 1.9 \%$ & $2 \%$ & $\pm 1.0 \%$ & $0.1 \% \pm 0.04 \%$ & $\frac{21 \pm 2.3}{22 \pm 16}$ \\
\hline Soil mean/sum & & & & & & & & & & & & & & & & & & & & & \\
\hline vắská & $L$ & $1.1 \pm 0.5$ & $5.37 \pm 0.4 \quad 4$. & $4.85 \pm 0.5 \quad 1$ & $1556 \pm 263$ & $766 \pm$ & \pm 146 & 11 & \pm 4.0 & 584 & \pm 272 & $6.4 \pm 0.8 \quad 0$ & $0.10 \pm$ & \pm 0.0 & $163 \pm 26$ & & & $40 \%$ & $\pm 3.0 \%$ & $1.2 \% \pm 0.1 \%$ & \\
\hline ká & $\mathrm{FH}$ & $10 \pm 1.7$ & $4.33 \pm 0.4$ & $3.43 \pm 0.4$ & $1862 \pm 590$ & $749 \pm$ & \pm 258 & 13 & \pm 0.8 & 109 & \pm 16 & $22 \pm 14$ & $5.1 \pm$ & \pm 5.9 & $180 \pm 38$ & $158 \pm 51$ & $\% \pm$ & $28 \%$ & & $.2 \% \pm 0$ & \\
\hline á́ & $0-10$ & $54 \pm 8.7$ & $4.13 \pm 0.2$ & $3.14 \pm 0.1$ & $326 \pm 122$ & $240 \pm$ & \pm 115 & 6.6 & \pm 0.6 & 32 & \pm 3.7 & $54 \pm 8.3$ & $34 \pm$ & \pm 6.9 & $92 \pm 7.7$ & $37 \pm$ & $\% \pm$ & $7.1 \%$ & $\pm 0.9 \%$ & $3 \% \pm 0$ & \\
\hline Kováíská & $10-20$ & $63 \pm 5.1$ & $4.47 \pm 0.1$ & $3.74 \pm 0.04$ & $64 \pm 33$ & $52 \pm$ & \pm 22 & 3.6 & \pm 1.2 & & \pm 3.5 & $35 \pm 4.2$ & $24 \pm$ & \pm 2.7 & $43 \pm 4.6$ & & $18 \% \pm$ & $2.8 \%$ & & $0.2 \% \pm 0.01 \%$ & \\
\hline$\frac{\text { Kovấrská }}{\text { Soil maan/sum }}$ & $20-40$ & $\frac{114 \pm 12}{243 \pm 7.0}$ & $\frac{4.63 \pm 0.14 .}{4.47 \pm 0.07 .3 .}$ & $\frac{4.08 \pm 0.04}{3.765 \pm 0.04}$ & $\frac{24 \pm 12}{189 \pm 61}$ & $\frac{14 \pm}{112 \pm}$ & $\begin{array}{l} \pm .7 \\
\pm .49\end{array}$ & $\frac{2.6}{4.2}$ & $\begin{array}{l} \pm 1.8 \\
\pm 1.0\end{array}$ & $\frac{11}{23}$ & $\begin{array}{l} \pm 1.6 \\
\pm 2.8\end{array}$ & $\frac{18 \pm 1.7}{31 \pm 2.3}$ & $\frac{9.1 \pm}{18 \pm}$ & $\begin{array}{l} \pm 1.5 \\
1.5\end{array}$ & $\frac{21 \pm 2.2}{50 \pm 4.9}$ & $\frac{2.8 \pm 1.2}{19 \pm 6.9}$ & $\frac{13 \% \pm 5.0 \%}{38 \%+10 \%}$ & $\frac{1.7 \%}{4.5 \%}$ & $\pm 0.2 \%$ & $\frac{0.1 \% \pm 0.01 \%}{0.22 \% \pm 0.01 \%}$ & $\frac{17 \pm 1.2}{19 \pm 0.9}$ \\
\hline Fláje & $\mathrm{L}$ & $1.2 \pm 0.3$ & $4.96 \pm 0.1$ & $4.25 \pm 0.12$ & $2596 \pm 264$ & $388 \pm$ & & 7.2 & \pm 2.8 & 292 & \pm 28 & $7.4 \pm 0.70$ & $0.10 \pm$ & \pm 0.0 & $177 \pm 16$ & $169 \pm$ & $96 \% \pm 0.6 \%$ & & & & \\
\hline & & $12 \pm 5.3$ & $4.81 \pm 0.2$ & $3.99 \pm 0.3 \quad 2$ & $2517 \pm 629$ & $755 \pm$ & \pm 107 & & \pm 1.8 & 135 & & & $3.2 \pm$ & \pm 4.6 & $205 \pm 30$ & $192 \pm$ & $\% \pm 5.8$ & & & $1.5 \% \pm 0$ & \\
\hline & $0-10$ & $17 \pm 9.5$ & $4.60 \pm 0.1$ & $3.68 \pm 0.1$ & $466 \pm 97$ & & & 8.3 & \pm & & \pm 13 & & & \pm 5.1 & $97 \pm 10$ & $50 \pm$ & $51 \% \pm 7.4 \%$ & $15 \%$ & & $1.0 \% \pm 0$ & \\
\hline & $10-20$ & $12 \pm 7.7$ & $4.73 \pm 0.1$ & $3.89 \pm 0.1$ & $287 \pm 53$ & $141 \pm$ & $\begin{array}{l} \pm 59 \\
+59\end{array}$ & 7.0 & \pm 2.1 & 45 & \pm 10 & $37 \pm 5.6$ & $24 \pm$ & \pm 4.3 & $65 \pm 12$ & $27 \pm 7.5$ & $42 \% \pm 4.4 \%$ & $10 \%$ & & $0.7 \% \pm 0.1$ & \\
\hline$\frac{\text { Flaje }}{\text { Soil mean/sum }}$ & & $\begin{array}{l}35 \div 26 \\
75 \pm 29\end{array}$ & $\begin{array}{ll}4.75 \\
4.72 \pm 0.1\end{array}$ & $\frac{3.99 \pm 0.1}{3.89 \pm 0.07}$ & $\frac{250 \pm / 1}{730 \pm 267}$ & $260 \pm$ & $\begin{array}{l} \pm 23 \\
\pm 67\end{array}$ & $\begin{array}{l}7.6 \\
7.6\end{array}$ & $\begin{array}{l} \pm 1.3 \\
\pm 0.9\end{array}$ & $\frac{30}{65}$ & $\begin{array}{l} \pm 7.6 \\
\pm 19\end{array}$ & $32 \pm 2.4$ & $\frac{21 \pm}{20 \pm}$ & $\begin{array}{l} \pm 2.1 \\
\pm \mathbf{3 . 0}\end{array}$ & $\begin{array}{l}33 \pm 6.1 \\
92 \pm 16.5\end{array}$ & $60 \pm 19.3$ & $\begin{array}{l}39 \% \pm \ldots .2 . \% \\
64 \% \pm 8.4 \%\end{array}$ & $7.5 \%$ & $\begin{array}{l} \pm 1.9 \% \\
\pm 2.9 \%\end{array}$ & $\begin{array}{r}0.5 \% \pm 0.1 \% \\
0.84 \% \pm 0.10 \%\end{array}$ & $\frac{14 \pm 2.1}{15 \pm 2.1}$ \\
\hline
\end{tabular}




\subsection{TRW chronologies}

The site TRW chronologies from the four sites vary in length from 59 to 106 tree rings. The

302

303

304

305

306

307

308

309

310

311

high reliability of all site chronologies was confirmed by the Rbar $(>0.48)$ and EPS $(>0.92)$ values, which remained above the threshold of 0.85 [39] for the entire study period. The high similarity among TRW chronologies at each site allows compilation of the mean TRW chronology (Rbar=0.40, EPS=0.97), covering the period from 1912 to 2017 (Fig. 9A).

Replication of the mean chronology decreased backwards and dropped below the 20 TRW series before 1950 (Fig. 9B). The mean chronology with an average annual growth rate of $2.75 \mathrm{~mm}$ shows a considerable decrease in annual growth starting in the $1950 \mathrm{~s}$. Three most significant growth reductions were revealed by the analysis of negative extremes in the periods 1979-1982, 1985-1988, and 1996-1997 when average tree-ring widths drop to 1.42, 1.67, and $1.49 \mathrm{~mm}$, respectively. Additionally, we detect seven missing rings between 19791982 and five in 1996-1997. The interval of the most pronounced growth reduction (19791988), likely initiated by the extremely cold and harsh winter of 1978/1979 [40], corresponds also to one of the highest concentrations of $\mathrm{SO}_{2}$ (Fig. 3).

Figure 9. (A) Raw (dotted line) and standardised (full line) TRW chronologies of all individual sites as well as Ore (Krušné) Mts. Mean correlation coefficient (CC) and mean GL (Gleichläufgkeit; Eckstein, Bauch 1969) indicate similarity among the site chronologies. (B) Indexed mean TRW chronology for Ore Mts. truncated for sample size (dotted line) of at least 20 TRW series. Black dots indicated negative extremes. 
Radial growth of conifers at high altitudes is primarily driven by growing season temperature

323

324 and global radiation [41]. However, the strong growth-temperature relationship was significantly reduced in the second half of the $20^{\text {th }}$ century when mountain forests of Central Europe experienced widespread and long-lasting effects related to acid deposition [42]. The coincidence of freezing temperatures in winter 1978/1979 and high concentrations of $\mathrm{SO}_{2}$ led to tree-ring width fluctuations and the weakening of the climate signal. In the 1980s, the radial growth of Norway spruce in the "Black Triangle" was not controlled by summer temperature at all. Extremely narrow tree-ring widths or even missing rings were detected under exceptionally unfavourable environmental conditions [14].

During the time of the highest sulfur emissions, the TRW reached its lowest values (Fig. 9). The TRW indices were reduced by $>40 \%$ during the 1980 s compared with their long-term mean (1950-2018). After the decline in sulfur deposition, the mean TRW indices increased, exceeding shortly the values from the period before the extreme emission load.

\subsection{Relationships between forest growth and acidification}

Direct $\left(\mathrm{SO}_{2}\right.$ concentrations, atmospheric deposition) and indirect (soil chemistry represented by soil $\mathrm{pH}, \mathrm{Bc} / \mathrm{Al}$ and soil base saturation) factors were evaluated to judge their relevance in the retrospectively observed reduced TRW (Fig. 9.).

\subsubsection{Atmospheric deposition and $\mathrm{SO}_{2}$ concentrations}

Atmospheric deposition of sulfur was identified as the most critical factor controlling reduced TRW for the period of tree lifetimes (Table III) for gneiss underlain Načetín (since 
1933) and Kovářská (since 1912). S deposition was not identified to be important for reduced

347 growth at basalt underlain Fláje (since 1959). S deposition was the only relevant explanatory parameter when the whole tree lifetime was analysed. TRW was reduced since 1979 (Fig. 9)

349 and has been fully recovered since 2000 . It represented deposition of about $300-350 \mathrm{meq} \cdot \mathrm{m}^{-}$

${ }^{2} \cdot \mathrm{yr}^{-1}$ at the beginning of reduction and ca. 250 at the end of the TRW reduction period (S1

Table III. Correlation matrix (R) and regression coefficients $\left(R^{2}\right)$ between the individual

parameters and TRW. Two intervals were correlated: (i) modelled annual atmospheric

deposition and soil chemistry for the life span of trees and (ii) modelled annual soil

1979-2017. Statistically significant $(p<0.05)$ values are displayed in red bold.

\begin{tabular}{|c|c|c|c|c|}
\hline & \multicolumn{2}{|c|}{$1850-2017$} & \multicolumn{2}{|c|}{ 1979-2017 } \\
\hline Načetín & $\mathrm{R}$ & $\mathrm{R}^{2}$ & $\mathrm{R}$ & $R^{2}$ \\
\hline Total S deposition & -0.40 & 0.16 & -0.49 & 0.24 \\
\hline Air $\mathrm{SO}_{2}$ imissions & & & -0.50 & 0.25 \\
\hline Soil pH & 0.23 & 0.05 & 0.18 & 0.03 \\
\hline Soil base saturation & 0.13 & 0.02 & -0.30 & 0.09 \\
\hline Soil Bc/Al & 0.14 & 0.02 & 0.06 & 0.00 \\
\hline \multicolumn{5}{|l|}{ Kovářská } \\
\hline Total S deposition & -0.38 & 0.14 & -0.72 & 0.51 \\
\hline Air $\mathrm{SO}_{2}$ imissions & & & -0.69 & 0.48 \\
\hline
\end{tabular}




\begin{tabular}{l|ll|ll} 
Soil $\mathrm{pH}$ & 0.28 & 0.08 & 0.56 & 0.31 \\
Soil base saturation & 0.34 & 0.11 & 0.59 & 0.35 \\
Soil Bc/Al & 0.26 & 0.07 & 0.49 & 0.24 \\
& & & & \\
& & & & \\
\multicolumn{1}{c|}{ Fláje } & -0.14 & 0.02 & -0.45 & 0.20 \\
Total S deposition & & & -0.45 & 0.20 \\
Air SO ${ }_{2}$ imissions & & & 0.30 & 0.09 \\
Soil pH & 0.07 & 0.01 & 0.34 & 0.11 \\
Soil base saturation & 0.07 & 0.00 & 0.34 & 0.05 \\
Soil Bc/Al & 0.02 & 0.00 & 0.23 & 0.05
\end{tabular}

TRW was additionally and deeply reduced in the years 1996-1997. Acid rime with extremely period in the mid-1990s. TRW reduction was observed at all sites (Fig. 9). Still, the most pronounced reduction was observed at the oldest stand at Kovářská and the lowest reduction was observed at the youngest stand, Fláje, underpinning the role of the vitality associated with young stands.

$\mathrm{SO}_{2}$ concentrations in the air were available for the period 1979-2017 from the Zinwald 
atmosphere) explain TRW better at naturally acidic plots with oldest spruce stands (Načetín, and subsequent needle injury and defoliation [12].

\subsubsection{Soil chemistry}

Soil chemistry did not show a statistically significant correlation with TRW for the lifetime of

trees at any site (Table III.). It also did not explain changes in tree growth changes shorter periods with rapid changes in pollution (1979-2017) for Načetín control and Fláje. The only site where soil chemistry, as well as air pollution, explains TRW is Kovářská. This site is naturally acidic (gneiss in bedrock), and it was first time limed in 1981 (Table I), during the most profound TRW depression (Fig. 9B). Thus soil solution $\mathrm{pH}, \mathrm{Bc} / \mathrm{Al}$ and base saturation increased significantly and monotonically (Fig. 8) from low values (BS of $6 \%$ in $40 \mathrm{~cm}$ ) to very high saturation ( $38 \%$ in 2018), significantly higher than the preindustrial estimate of $20 \%$. 


\section{Synthesis}

Long-term changes in soil chemistry (soil $\mathrm{pH}$, base saturation and $\mathrm{Bc} / \mathrm{Al}$ ratio) did not explain

the observed decline in TRW at both of our sites for which data are available (Table III)

despite the depletion of nutrient cations and enhanced concentration of potentially toxic Al

in the soil solution that has frequently been hypothesised to lead to deterioration of forest

health. The molar $\mathrm{Bc} / \mathrm{Al}$ ratio $((\mathrm{Ca}+\mathrm{Mg}+\mathrm{K}) / \mathrm{Al})$ has been widely used as a criterion for the

404

405

406

407

408

409

410 than the unlimed Načetín control (the same bedrock), where no correlation was observed. risk of tree damage $[43,44,45]$. Experiments with seedlings by Sverdrup et al. [43] showed that increased mortality occurred if the $\mathrm{Bc} / \mathrm{Al}$ ratio was lower than 1 . Field data from the Czech Republic [45] suggested that increasing tree damage occurred with decreasing $\mathrm{Bc} / \mathrm{Al}$ in the soil solution of the rooting zone in Norway spruce stands. On the other hand, this concept's limitation was shown by De Witt et al. [46]. They found that of the base cations, only reduction of $\mathrm{Mg}$ uptake occurred after long-term experimental addition of $\mathrm{AlCl}_{3}$ to the rooting zone of Norway spruce in southern Norway. Our observations support the hypothesis that direct injury of the assimilatory organs is more important for tree damage, at least in the areas where extremely high $\mathrm{SO}_{2}$ concentrations, as well as $\mathrm{S}$ deposition, occurred in the past [e. g. 1, 14, 42].

If the shorter period $1979-2017$ is examined (Table III), statistically significant correlations for soil $\mathrm{pH}$, base saturation, and Bc/Al were observed for Kovářská only (Table III). This plot was limed three times since 1981 (Fig. 8), and soil chemistry became less acidic and base-rich The magnitude of soil chemistry change at Kovářská was very pronounced in comparison to 
Načetín control (Fig. 8), but TRW changes were similar and no statistical difference between

The minor role of soil chemistry was also manifested at naturally well buffered and also massively limed Fláje. Very high base saturation before the liming and supersaturation after that (Fig. 8) did not eliminate TRW decline in the 1970s and 1980s (Fig. 9). published by Kolář et al. [14]. They found that TRW of Norway spruce declined significantly at high altitudes since the 1970 s and recovered fully around 2000 when acidic deposition declined. One plot from five investigated was limed by $5 \mathrm{t} \cdot \mathrm{ha}^{-1}$ of dolomitic limestone in the mid-1980s. Liming did not affect TRW, and all five sites recovered synchronously as the acid deposition declined.

The fact that canopy injury was the most important for TRW reduction was well documented

followed by a short but deep depression in the tree ring width, even though soil chemistry did not show any deviation from the observed long-term trends (Fig. 6 and Fig. 8).

Our results suggest that the direct impact of acidic deposition from high $\mathrm{SO}_{2}$ concentrations and/or sulfur deposition was the main driver of forest decline. Soil chemistry to a depth of $40 \mathrm{~cm}$ most probably did not play a crucial role in the observed forest dieback in the heavily polluted so-called "Black Triangle" of Central Europe, formerly one of the most $\mathrm{SO}_{2}$-polluted areas in the world. Soil liming did not appear to help recover tree growth from chronic stress as has been suggested and often used as an argument for repeated liming [37]. Liming may help reduce soil acidity and increase the amount of deficient base cations (Ca and $\mathrm{Mg}$ ). Still, concerning tree growth measured as changes in TRW, our study showed no positive effects 
of liming. Other authors [e. g. 47] have also found that enhanced radial growth of trees did not occur after dolomitic limestone application.

444 We cannot reject altogether the hypothesis that forest growth might be negatively affected by soil chemistry, as the uppermost organic and mineral soil down to $10 \mathrm{~cm}$ slightly recovered at long-term observed Načetín control plot (Fig. 6). In contrast, deeper mineral soil down to $40 \mathrm{~cm}$ became even more acidic during the last few decades (Fig. 6). Very acidic forest soils (down to $30 \mathrm{~cm}$ ) were detected at $31 \%$ of 1599 semi-randomly selected soil samples taken between 2006-2009 in the Czech Republic [48], but significant forest decline which can be attributed to soil acidification was not observed during the same time [49]. As soil recovery in the uppermost rooting zone. acidic deposition caused a deterioration in soil chemistry, but negative effects on Norway spruce growth did not occur. Direct effects on foliage, reducing primary productivity, appear to be more critical for reducing tree growth than soil acidification.

\section{Acknowledgements}


granted by Czech Ministry of Education, Youth and Sport. Pavla Holečková from Czech

6. Literature Cited

1. Moldan B, Schnoor JL. Czechoslovakia: examining a critically ill environment. Environ.

2. Hůnová I. Ambient Air Quality in the Czech Republic: Past and Present. Atmosphere.

3. Kubíková J. Forest dieback in Czechoslovakia. Vegetatio. 1991; 93: 101-108.

4. Sullivan TJ, Driscoll CT, Beier CM, Burtraw D, Fernandez IJ, Galloway JN, et al. Air pollution success stories in the United States: the value of long-term observations. Environ Sci Policy. 2018; 84: 69-73. doi: 10.1016/j.envsci.2018.02.016.

5. Grennfelt $P$, Engleryd A, Forsius $M, \operatorname{Hov} \varnothing$, Rodhe $H$, Cowling E. Acid rain and air pollution - 50 years of progress in environmental science and policy. Ambio. 2020; 49: 849-864. doi: 10.1007/s13280-019-01244-4.

6. Oulehle F, Kopáček J, Chuman T, Černohous V, Hůnová I, Hruška J, et al. Predicting sulphur and nitrogen deposition using a simple statistical method. Atmospheric Environ. 2016; 140: 456 - 468. doi: 10.1016/j.atmosenv.2016.06.028 Council of Ministers. Nord. 1990; 98. 
8. De Vries W, Reinds GJ, Posch M. Assessment of critical loads and their exceedance on European forests using a one-layer steady-state model. Water, Air, and Soil Pollut. 1994; 72: 357-394.

9. Godbold DL, Fritz H-W, Jentschke G, Meesenburg H, Rademacher P. Root turnover and root necromass accumulation of Norway spruce (Picea abies) are affected by soil acidity. Tree Physiol. 2003; 23: 915-921. doi: https://doi.org/10.1093/treephys/23.13.915

10. Kandler O, Innes JL. Air pollution and forest decline in Central Europe: Environ. Pollut. 1995; 90(2): 171-180.

11. Schulze E-D. Air Pollution and Forest Decline in a Spruce (Picea abies) Forest. Science. 1989; 244 (4906): 776-783. DOI: 10.1126/science.244.4906.776

12. Krause GMH. Impact of air pollution on above-ground plant parts of forest trees. In: Mathy p (ed) Air Pollution and ecosystems. Riedel Publ. Co. Dordrecht; 1988. pp. 168216.

13. Büntgen U. Urban O. Krusic PJ. et al. Recent European drought extremes beyond Common Era background variability. Nat. Geosci. 2021; 14: 190-196. https://doi.org/10.1038/s41561-021-00698-0

14. Kolář $T$, Čermák $P$, Oulehle $F$, Trnka $M$, Štěpánek $P$, Cudlín $P$, et al. Pollution control enhanced spruce growth in the "Black Triangle" near the Czech-Polish border. Sci Total Environ. 2015; 538: 703-711. 
15. Black BA, Griffin D, van der Sleen P, Wanamaker AD Jr, Speer JH, Frank DC, et al. The value of crossdating to retain high-frequency variability, climate signals, and extreme events in environmental proxies. Glob Change Biol. 2016; 22(7): 2582-2595. disturbance history with tree regeneration and diversity in an old-growth forest in northern Japan. Perspect. Plant Ecol. Evol. Syst. 2016; 21: 1-131. conifers along elevational and latitudinal gradients. Int J Climatol. 2017; 37(5): 259326051.

18. Rybníček M, Kolář T, Ač A, Balek J, Koňasová E, Trnka M, et al. Non-pooled oak (Quercus spp.) stable isotopes reveal enhanced climate sensitivity compared to ring widths. Clim Res. 2021; 83: 27-41. https://doi.org/10.3354/cr01632 through a forest ecosystem submitted to extremely high atmopsheric pollution inputs (Czech Republic). Ann Sci For. 1993; 50: 147-157. changes in forest carbon and nitrogen cycling caused by declining sulphur deposition. Glob Change Biol. 2011; 17: 3115-3129. coniferous and broadleaf forests under experimentally elevated acidity and nitrogen addition. Plant Soil. 2021; 463: 471-485. doi: https://doi.org/10.1007/s11104-021- 
22. Gut U, Árvai M, Bijak S, Camarero JJ, Cedro A, Cruz-García R, et al. No systematic effects of sampling direction on climate-growth relationships in a large-scale, multispecies tree-ring data set. Dendrochronologia. 2019; 57: 125624.

23. Knibbe B. PAST4 - Personal Analysis System for Treering Research Version 4. Instruction Manual. Vienna: SCIEM/Bernhard Knibbe; 2004.

24. Grissino-Mayer HD. Evaluating crossdating accuracy: a manual and tutorial for the computer program COFECHA. Tree Ring Res. 2001; 57 (2): 205-221.

25. Cook ER, Peters K. The smoothing spline: a new approach to standardizing forest interior tree-ring width series for dendroclimatic studies. Tree Ring Bull. 1981; 41: 45-53.

26. Cook ER, Krusic PJ. ARSTAN v. 41d: a Tree-ring Standardization Program Based on Detrending and Autoregressive Time Series Modeling, with Interactive Graphics. Palisades; New York; USA: Tree-Ring Laboratory: Lamont-Doherty Earth Observatory of Columbia University; 2005.

27. Büntgen U, Frank DC, Wilson R, Carrer M, Urbinati C, Esper J. Testing for tree-ring divergence in the European Alps. Glob Chang Biol 2008; 14: 2443-2453.

28. Cook ER, Peters K. Calculating unbiased tree-ring indices for the study ofclimatic and environmental change. Holocene. 1997; 7: 361-370.

29. Eckstein D, Bauch J. Beitrag zur Rationalisierung eines dendrochronologischen Verfahrens und zur Analyse seiner Aussagesicherheit. Forstwissenschaftliches Zentralblatt. 1969; 88: 230-250. 
30. Huntington TG, Ryan DF, Hamburg SP. Estimating soil-nitrogen and carbon pools in northern hardwood forest ecosystem. Soil Sci Soc Am J. 1988; 52: 1162-1167.

31. Cosby BJ, Hornberger GM, Galloway JN, Wright RF. Time scales of catchment acidification: a quantitative model for estimating freshwater acidification. Environ Sci Technol. 1985; 19: 1144-1149.

32. Cosby BJ, Ferrier RC, Jenkins A, Wright RF. Modelling the effects of acid deposition: refinements, adjustments and inclusion of nitrogen dynamics in the MAGIC model. Hydrol Earth Syst Sci. 2001; 5: 499-518.

33. Oulehle F, Cosby BJ, Wright RF, Hruska J, Kopacek J, Kram P, et al. Modeling soil nitrogen: the MAGIC model with nitrogen retention linked to carbon turnover using decomposer dynamics. Environ Pollut. 2012; 165: 158-166. doi: https://doi.org/10.1016/j.envpol.2012.02.021

34. Sächsisches Landesamt für Umwelt, Landwirtschaft und Geologie [cited 17 July 2021]. Available from: https://www.lfulg.sachsen.de/.

35. Kopáček J, Hejzlar J, Krám P, Oulehle F, Posch M. Effect of industrial dust on precipitation chemistry in the Czech Republic (Central Europe) from 1850 to 2013. Water Res. 2016; 103: 30-37. doi: https://doi.org/10.1016/j.watres.2016.07.017. 36. Krejčí R. Poškození smrkového lesa v Krušných horách. Vesmír. 2001; 10: 576-80.

37. Kubelka L, Karásek A, Rybář V, Badalík V, Slodičák M. Obnova lesa v imisemi poškozované oblasti severovýchodního Krušnohoří. Praha: Ministerstvo zemědělství České republiky; 1992. 
38. Hruška J, Cienciala E. Long-term acidification and nutrient degradation of forest soils limiting factors of forestry today. Praha: Ministry of the Environmet of the Czech Republic; 2003. ISBN 80-7212-190-1.

39. Wigley TML, Briffa KR, Jones PD. On the average value of correlated time series, with applications in dendroclimatology and hydrometeorology. J Clim Appl Meteorol. 1984; 23: 201-213.

40. Rein F, Štekl J. The extremeness of the cold front of Dec. 31, 1978 over the CSR. Trav Géophys. 1981; 29: 379-404.

41. Kolář T, Čermák $P$, Trnka M, Žid T, Rybníček M. Temporal changes in the climate sensitivity of Norway spruce and European beech along an elevation gradient in Central Europe. Agric For Meteorol. 2017; 239: 24-33. doi: 10.1016/j.agrformet.2017.02.028.

42. Rydval M, Wilson R. The impact of industrial SO2 pollution on North Bohemia conifers. Water Air Soil Pollut. 2012; 223 (9): 5727-5744. doi: http://dx.doi.org/10.1007/s11270-012-1310-6.

43. Sverdrup $H$, Warfvinge $P$, Rosén $K$. A model for the impact of soil solution Ca:Al ratio, soil moisture and temperature on tree base cation uptake. Water Soil Air Pollut. 1992; 61: 365-373.

44. Cronan CS, Grigal DF. Use of calcium/aluminum ratios as indicators of stress in forest ecosystems. J Environ Qual. 1995; 24: 209-216. 
45. Hruška J, Cudlín P, Krám P. Relationship between Norway spruce status and soil water base cations/aluminum ratios in the Czech Republic. Water Air Soil Pollut. 2001; 130: 983-988.

46. de Wit HA, Eldhuset TD, Mulder J. Dissolved Al reduces Mg uptake in Norway spruce forest: Results from a long-term field manipulation experiment in Norway. For Ecol Manage. 2010; 259: 2072- 2082. doi: https://doi.org/10.1016/j.foreco.2010.02.018.

47. Schaaf W. Evaluation of different magnesium fertilization strategies. In: Hüttl RF, Schaff WW, editors. Magnesium deficiency in Forest Ecosystems. Kluwer Academic Publishers; 1997. pp. 333-355.

48. Šantrůčková H, Cienciala E, Kaňa J, Kopáček J. The chemical composition of forest soils and their degree of acidity in Central Europe. Sci Total Environ. 2019; 687: 96103.

49. Cienciala E, Russ R, Šantrůčková H, Altman J, Kopáček J, Hůnová I, et al. Discerning environmental factors affecting current tree growth in Central Europe. Sci Total Environ. 2016; 573: 541-554.

50. de Vries W, Dobbertin HH, Solberg SH, van Dobben HF, Schau F. Impacts of acid deposition, ozone exposure and weatherconditions on forest ecosystems in Europe: an overview. Plant Soil. 2014; 380: 1-45, doi: 10.1007/s11104-014-2056-2.

51. Oulehle F, Hofmeister J, Cudlín P, Hruška J. The effect of reduced atmospheric deposition on soil and soil solution chemistry at a site subjected to long-term acidification, Načetín, Czech Republic. Sci Total Environ. 2006; 370: 532- 544. doi: https://doi.org/10.1016/j.scitotenv.2006.07.031 


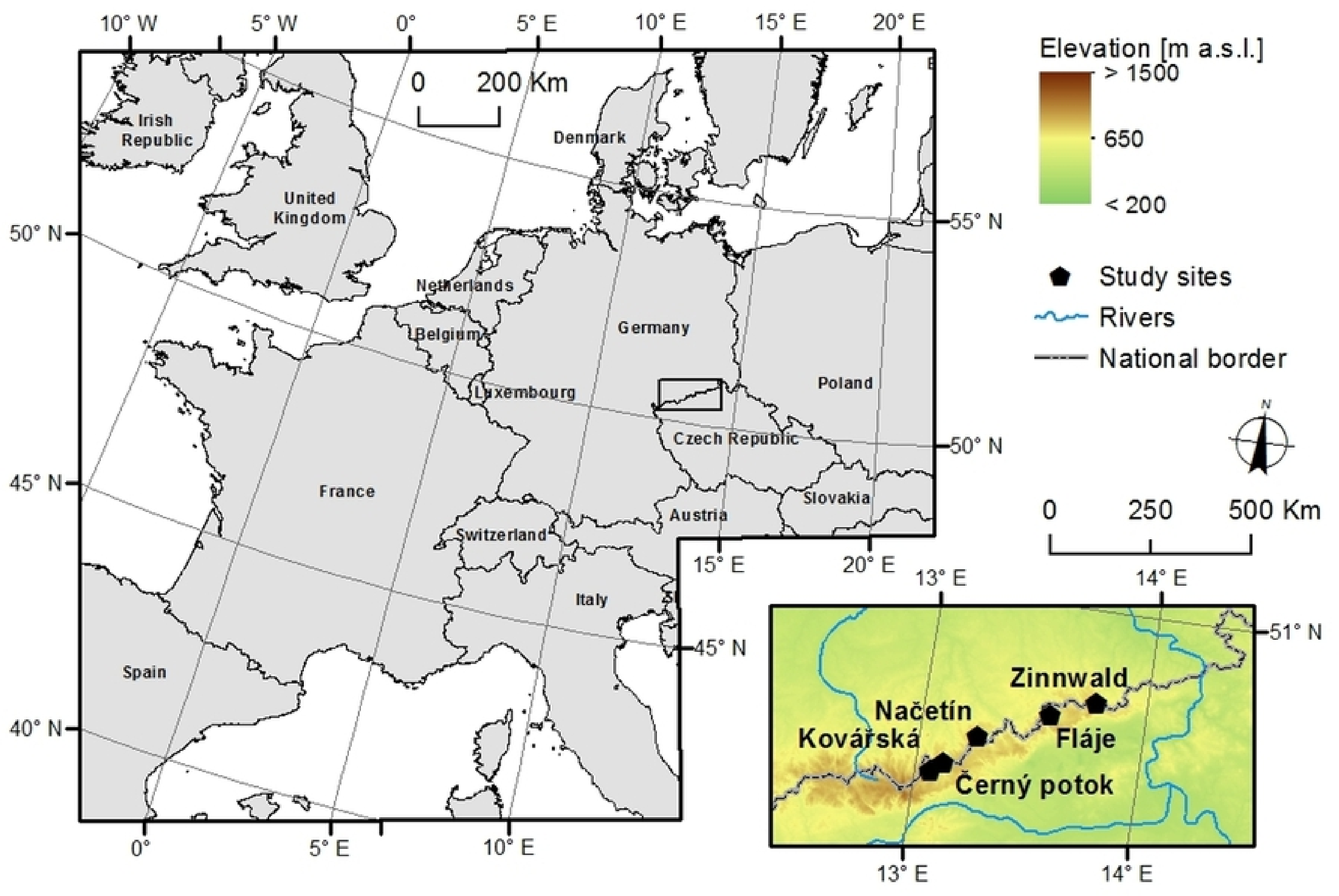

Figure1 


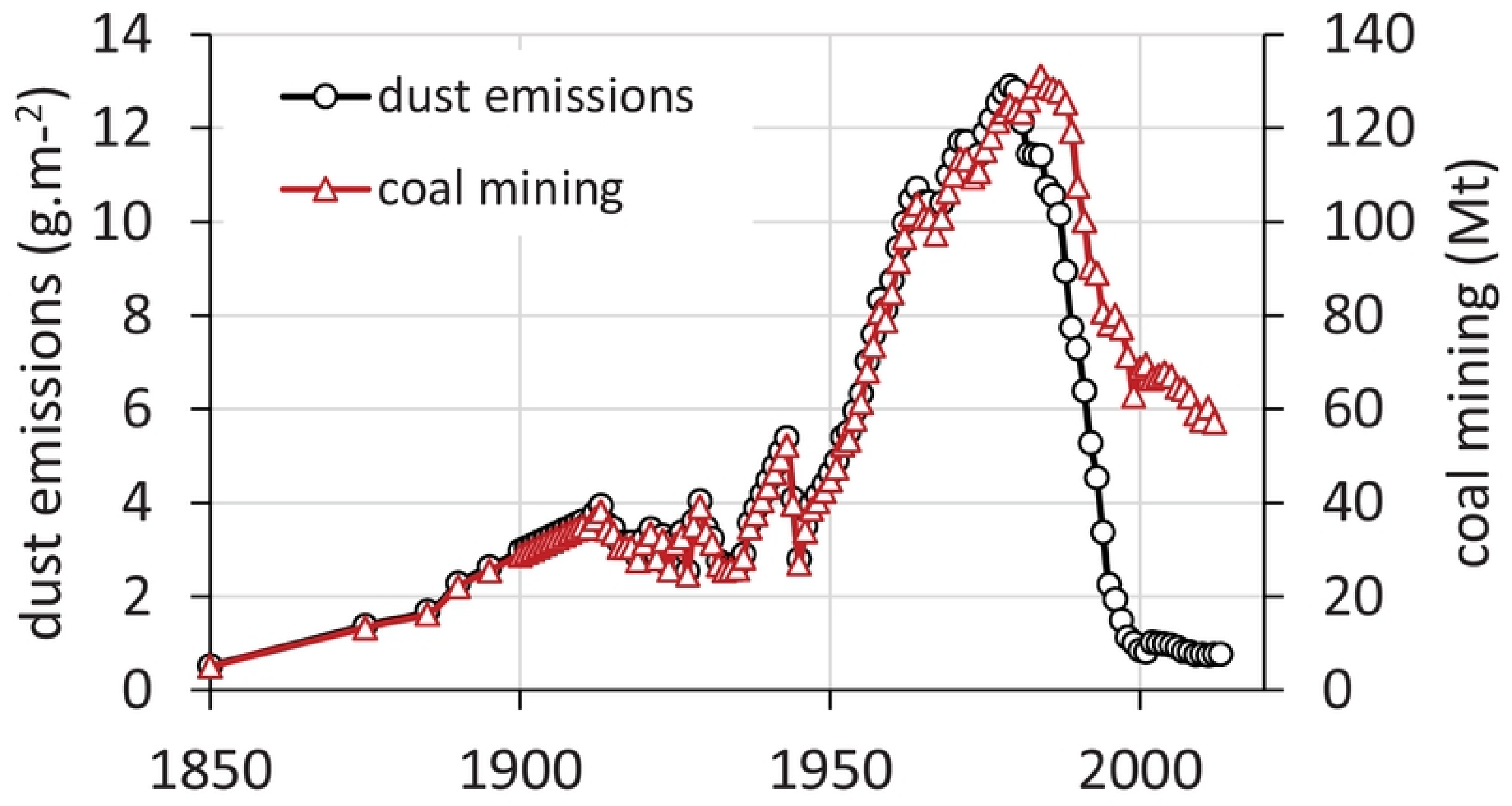

Figure2 


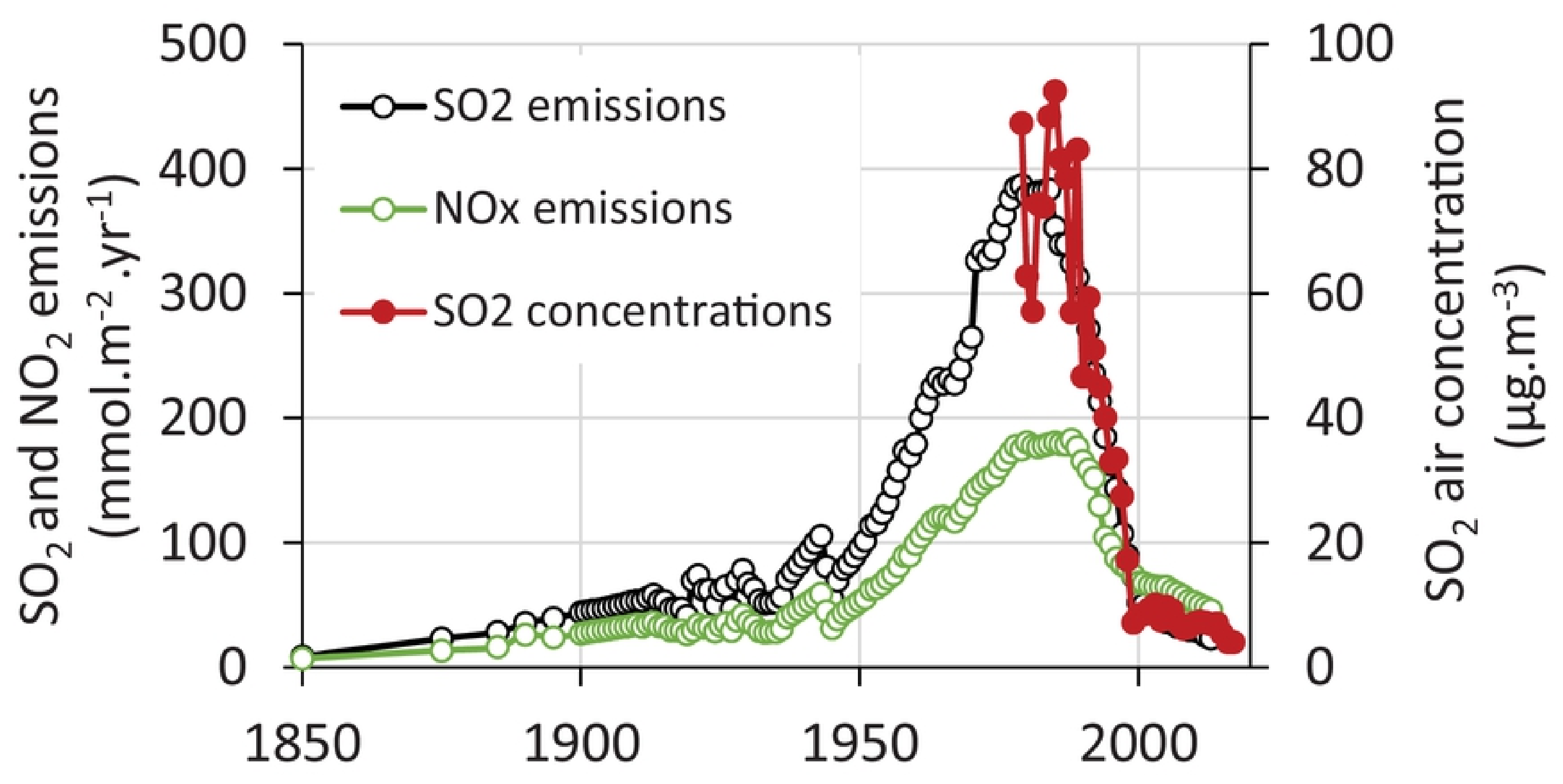

Figure3 


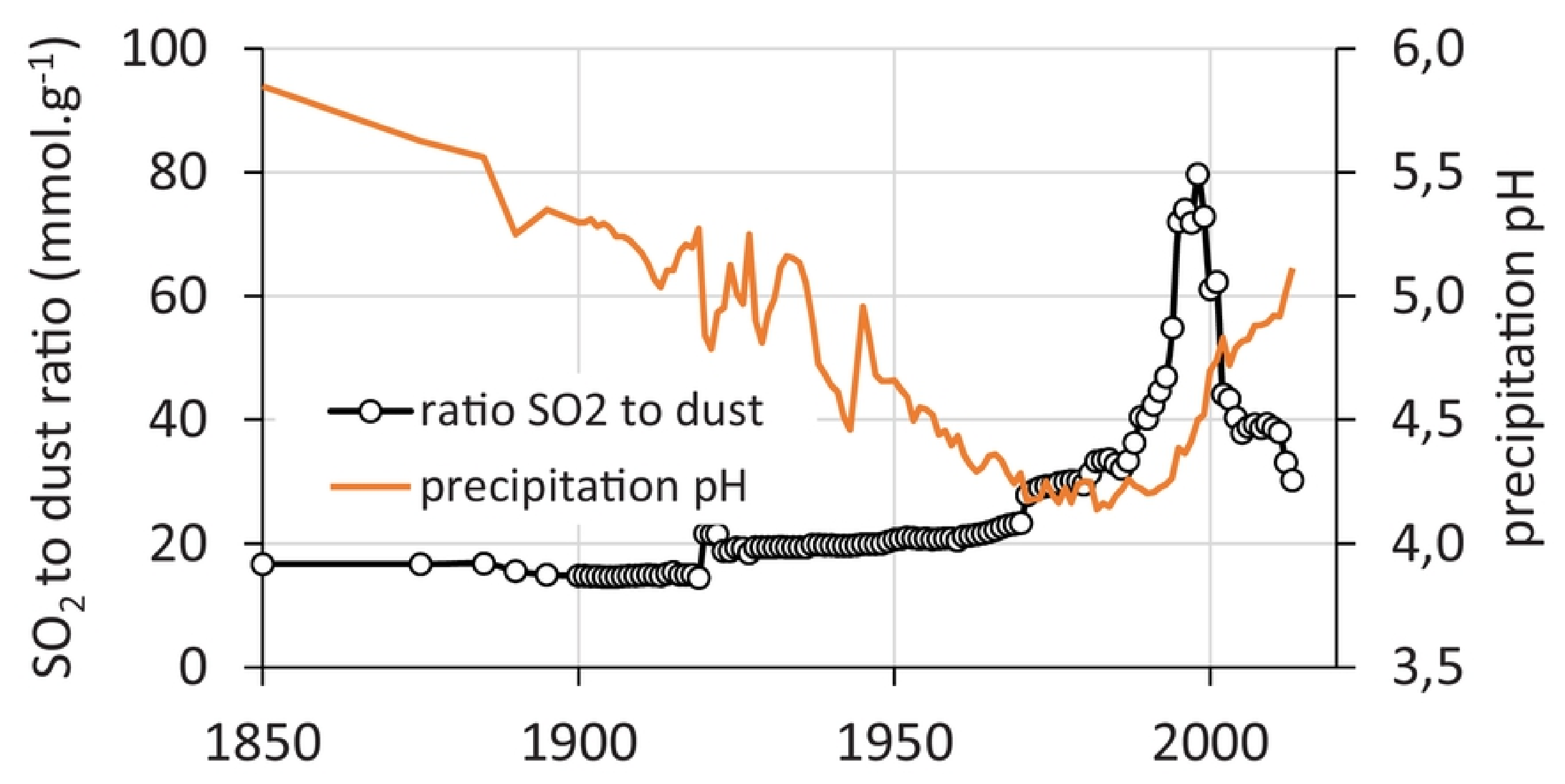

Figure4 


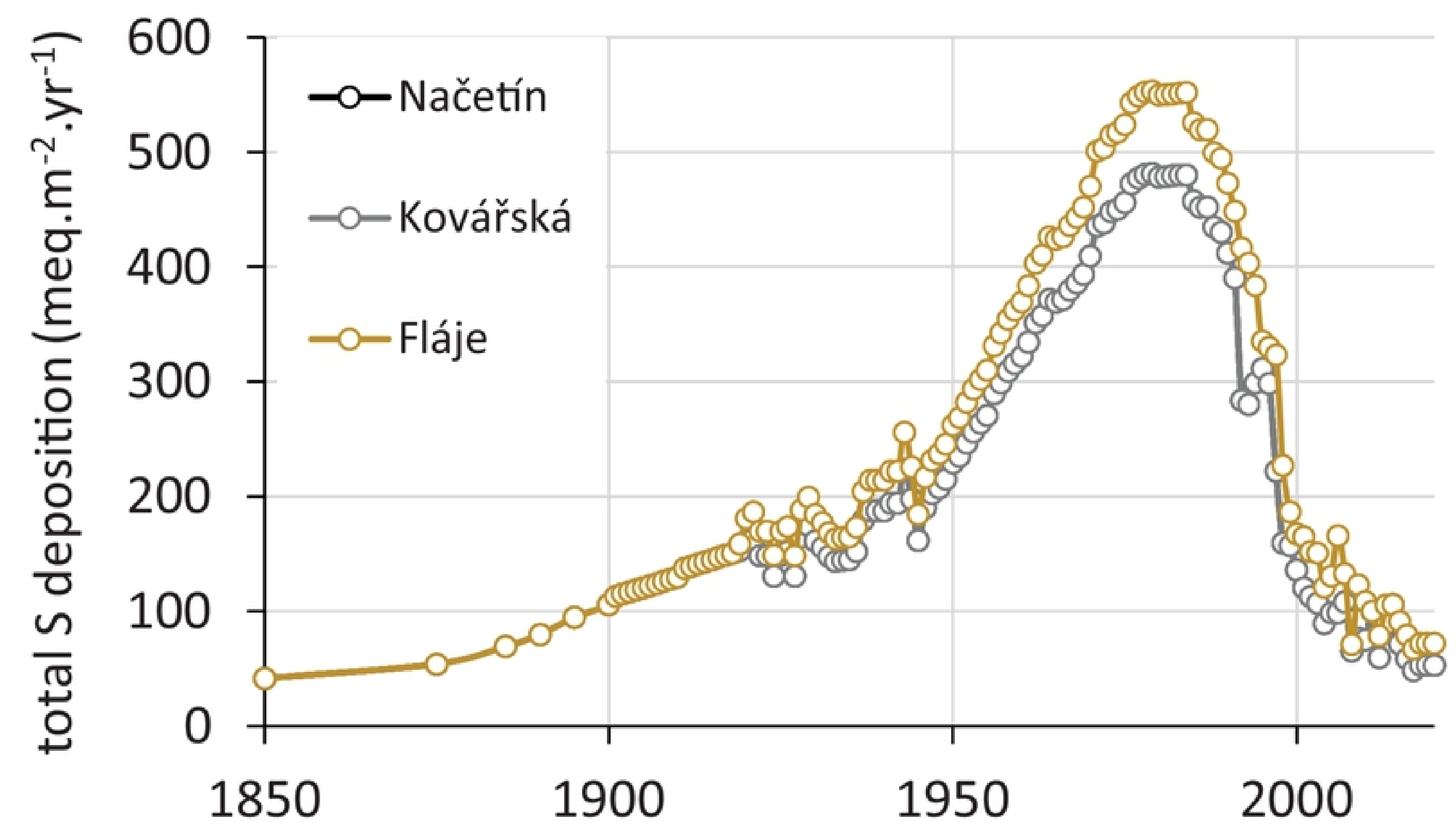

Figure5 


\section{Soil pH}

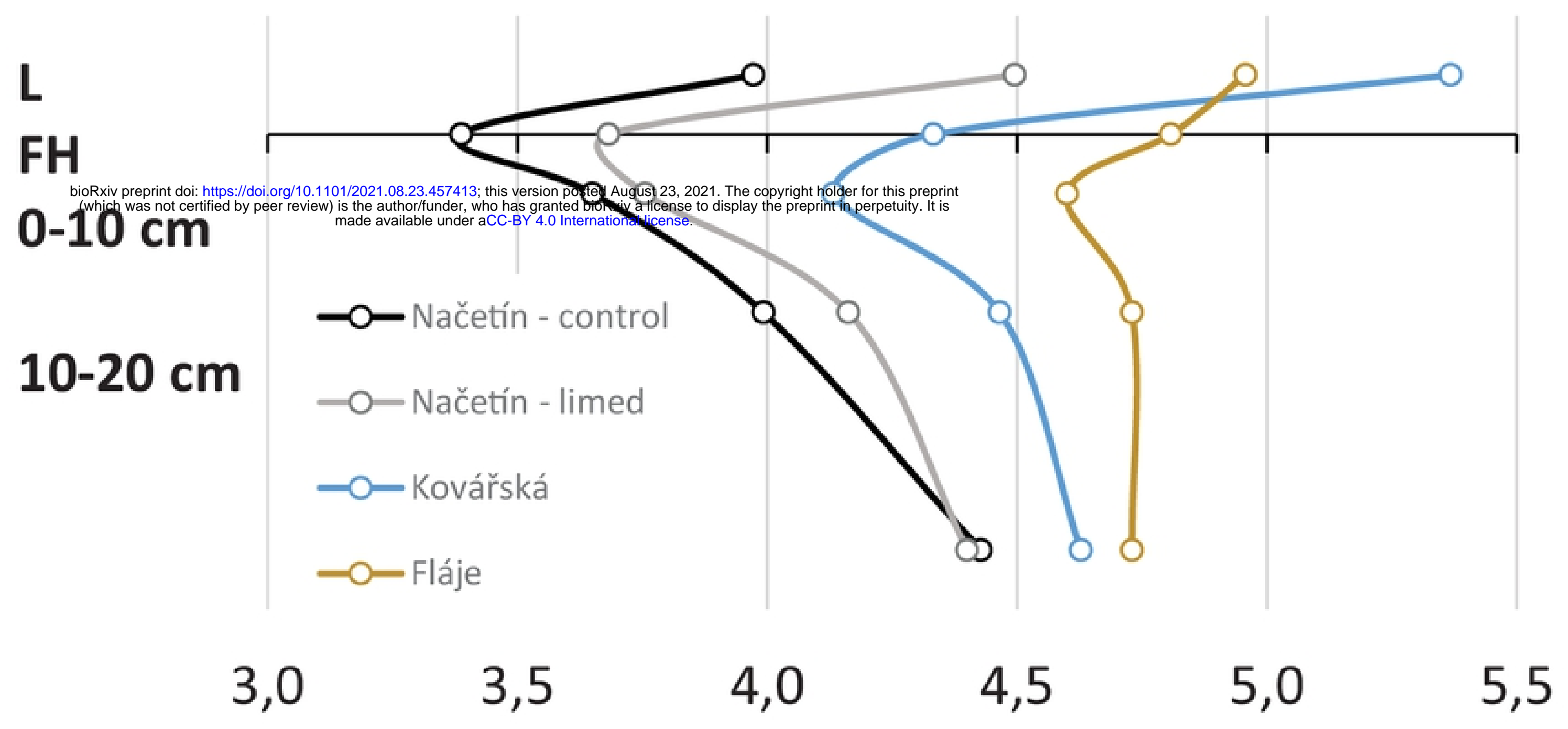

Soil base saturation

L

FH

0-10 cm

$10-20 \mathrm{~cm}$

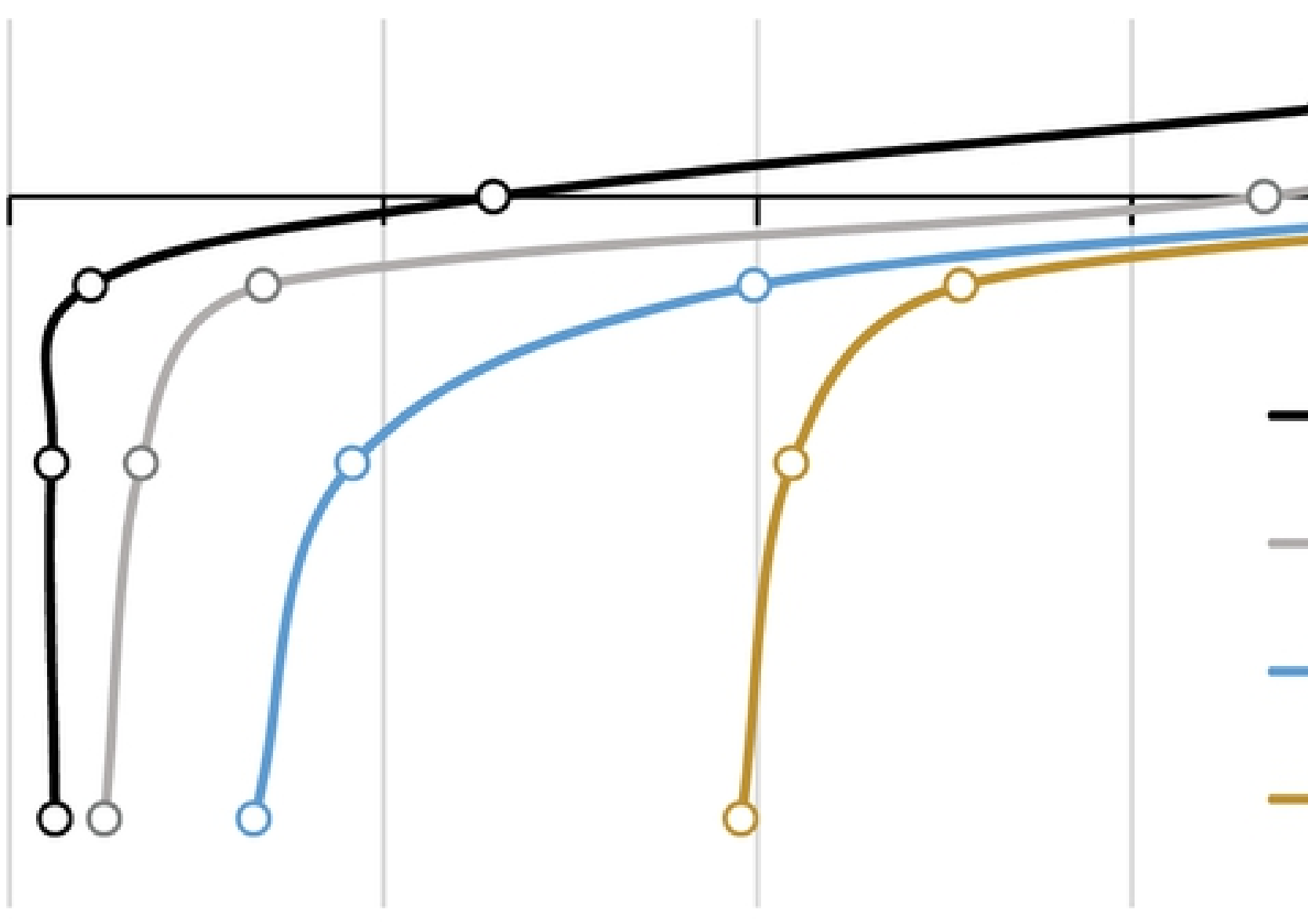

$\longrightarrow$-Načetín - control

-O-Načetín - limed

——Kovářská

——Fláje

$0 \%$

$20 \%$

$40 \%$

$60 \%$

$80 \%$

Figure7 


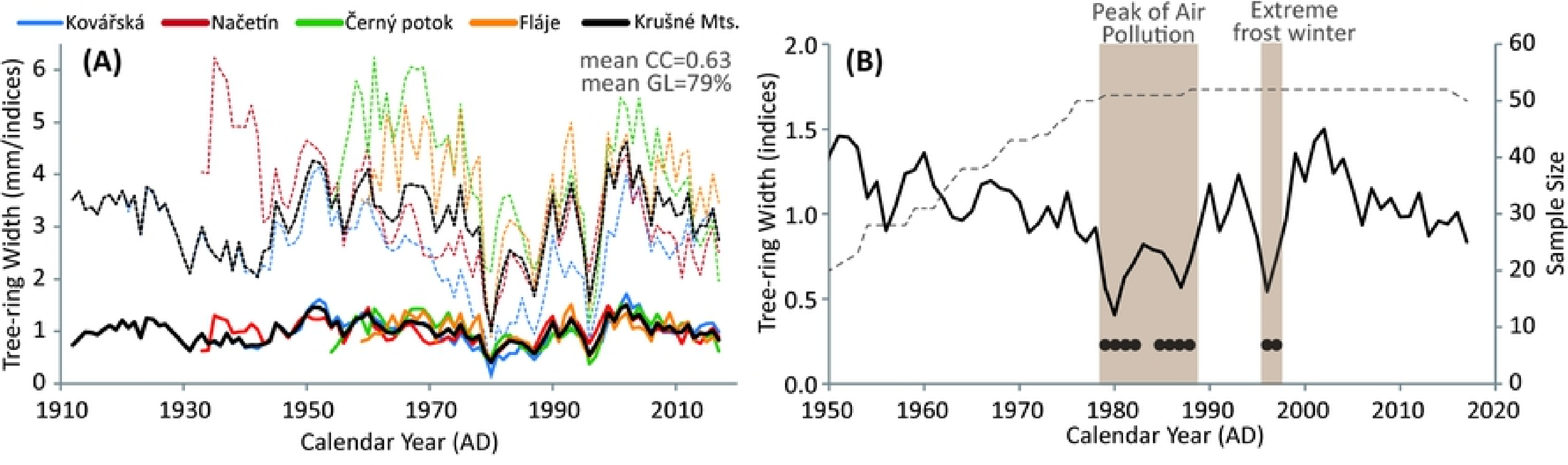

Figure9 


\section{Dolomitic limestone dissolution kinetics}

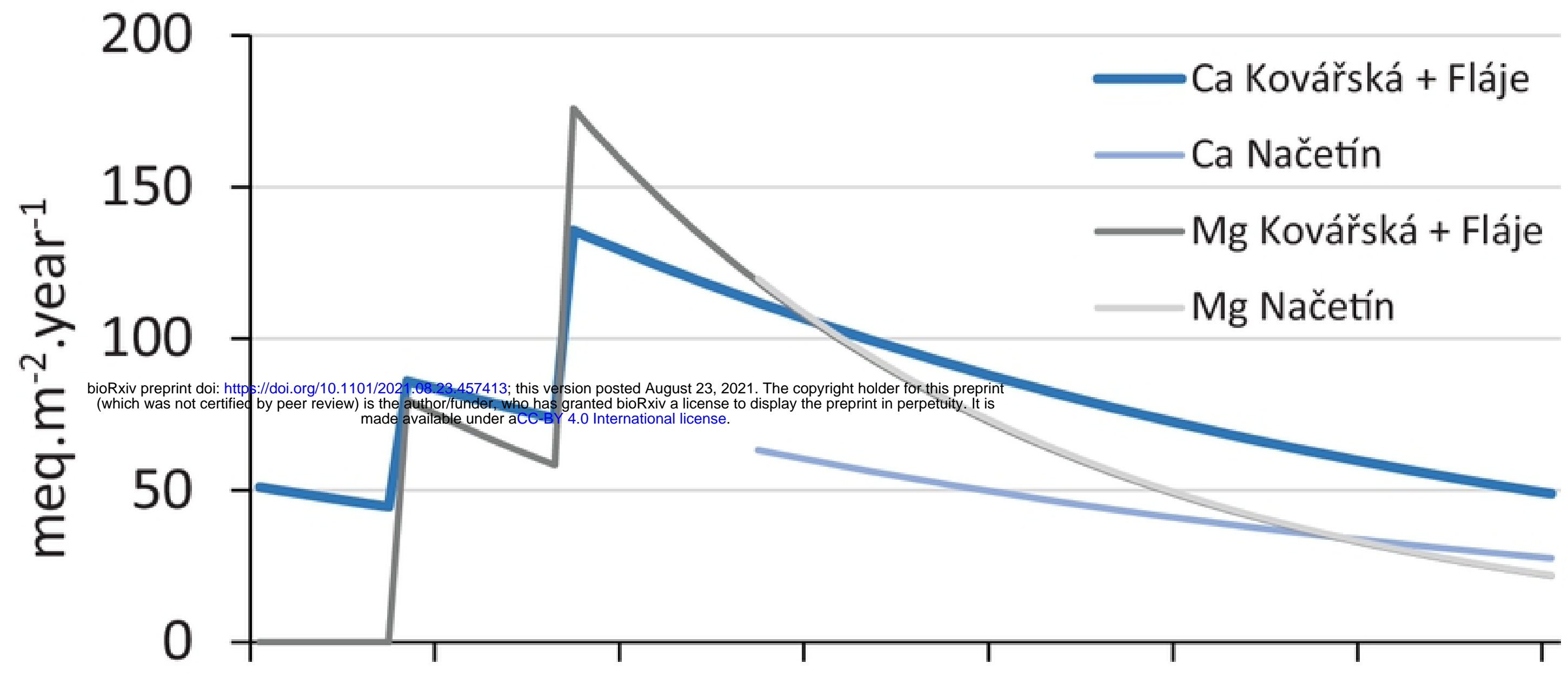

$\begin{array}{llllllll}1980 & 1990 & 2000 & 2010 & 2020 & 2030 & 2040 & 2050\end{array}$

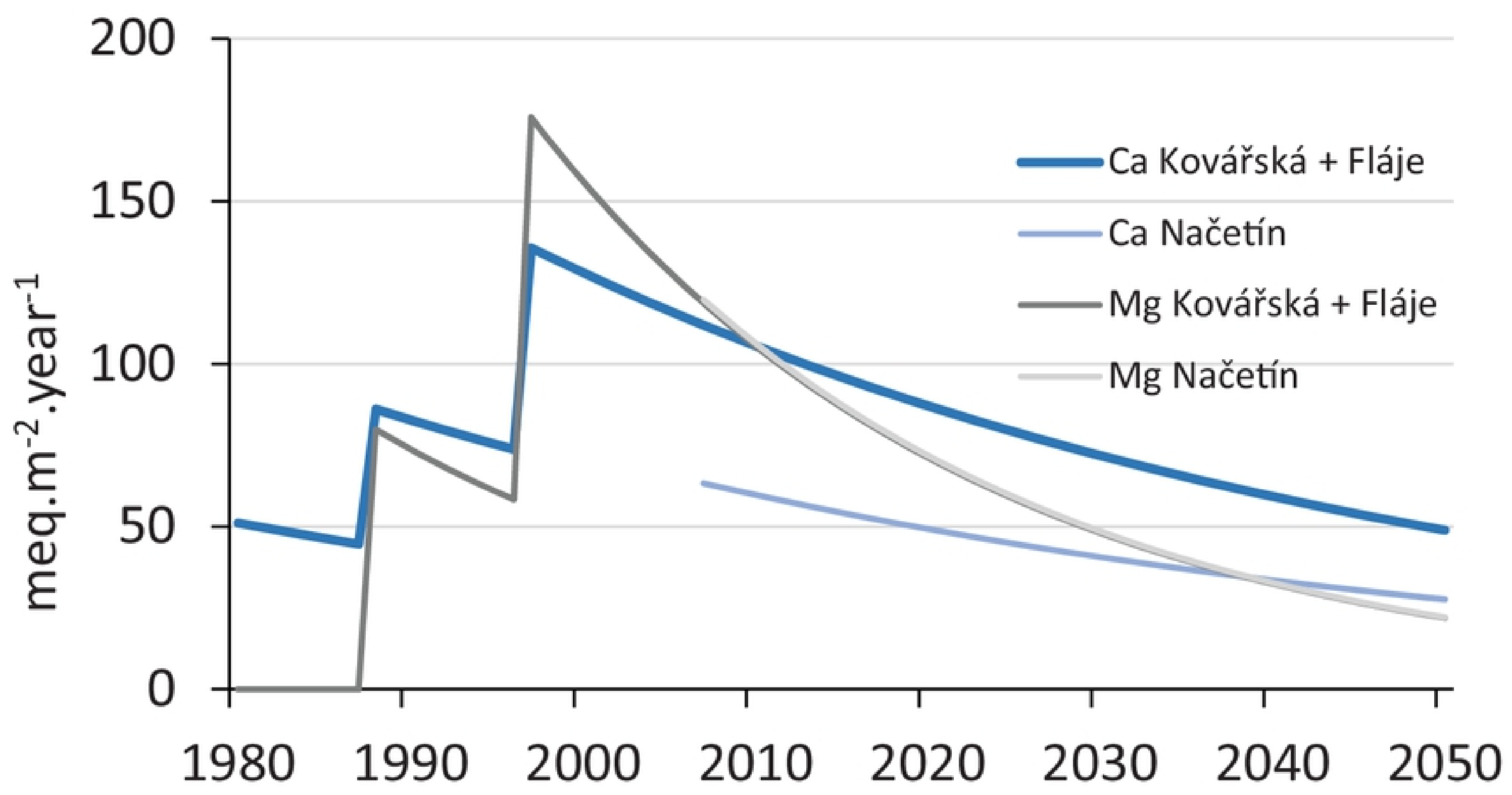

S1Annex FigureS1.1.1 

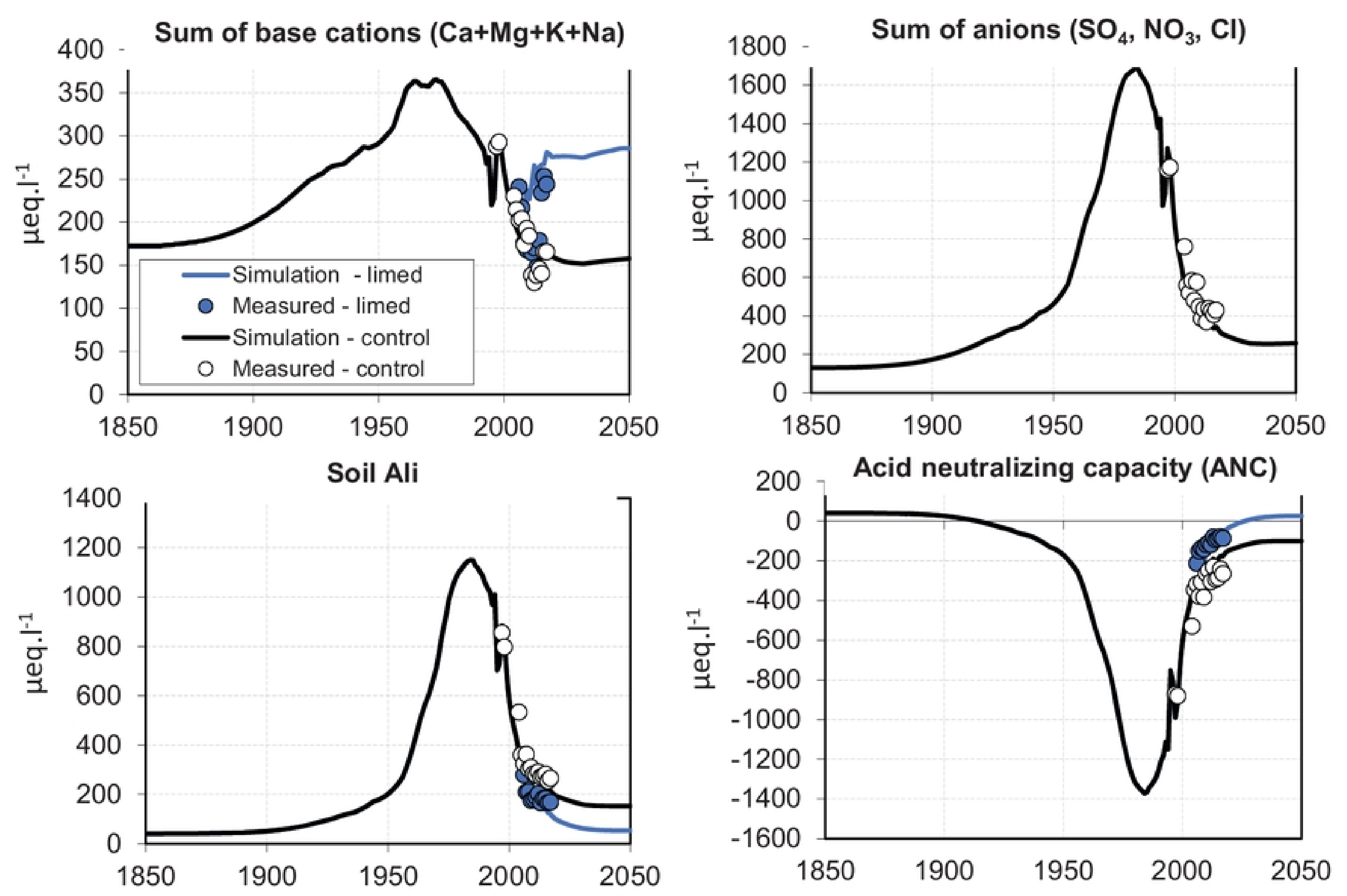

S1Annex FigureS1.2.1 


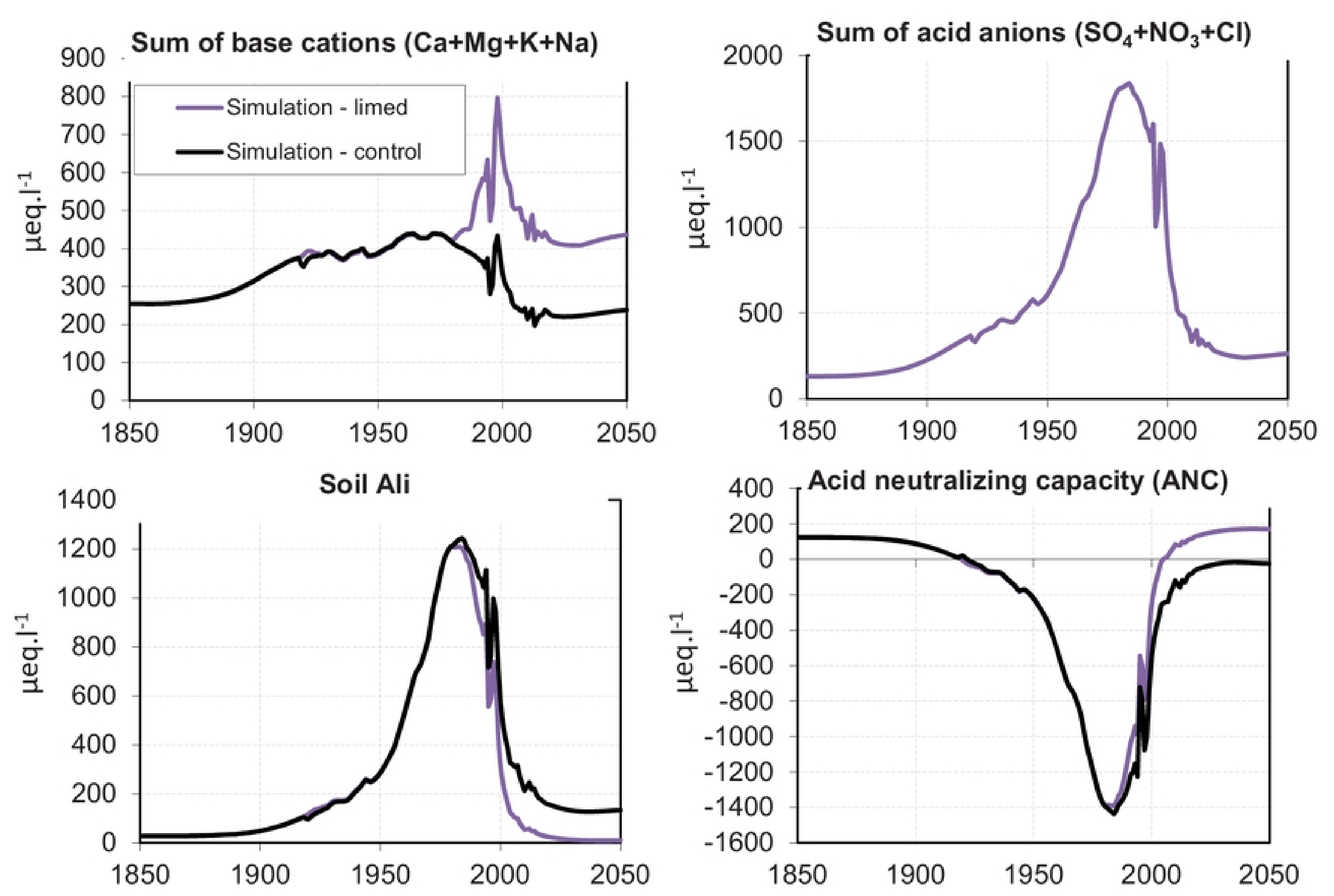

S1Annex FigureS1.2.3 
Načetín

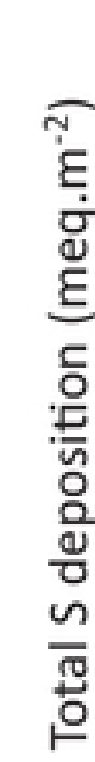

600

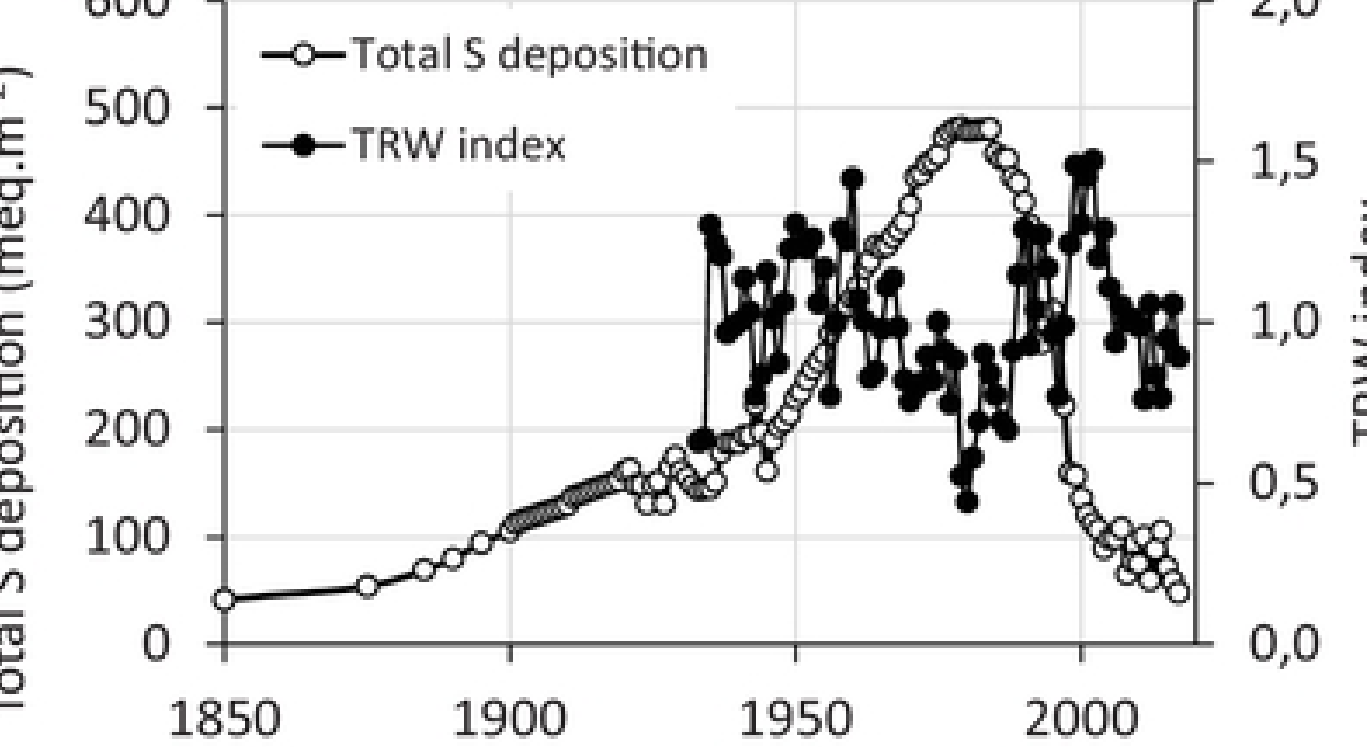

Kovářská

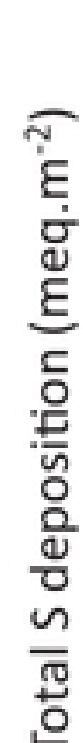

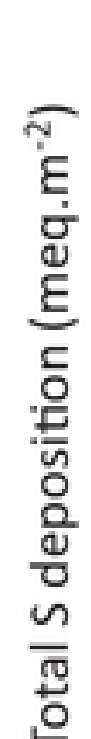

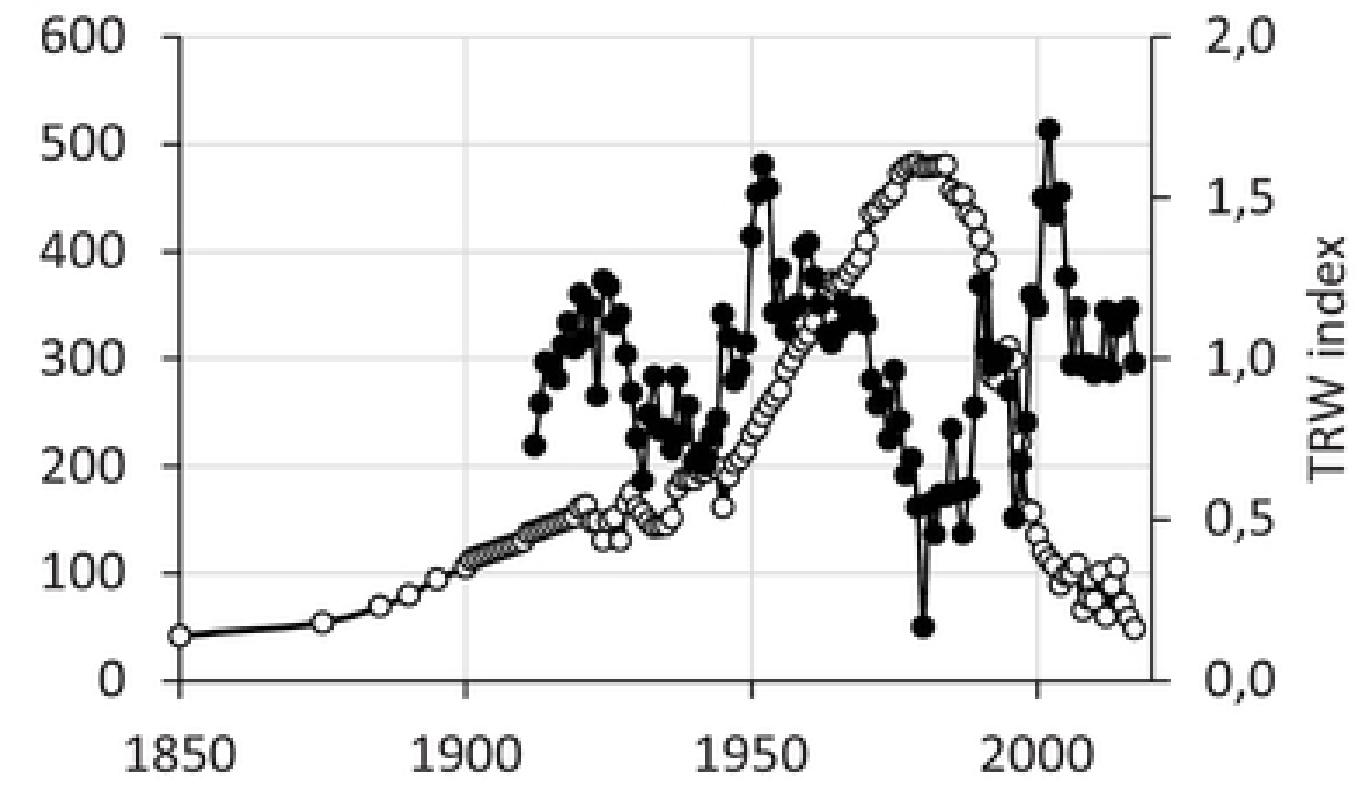

Fláje

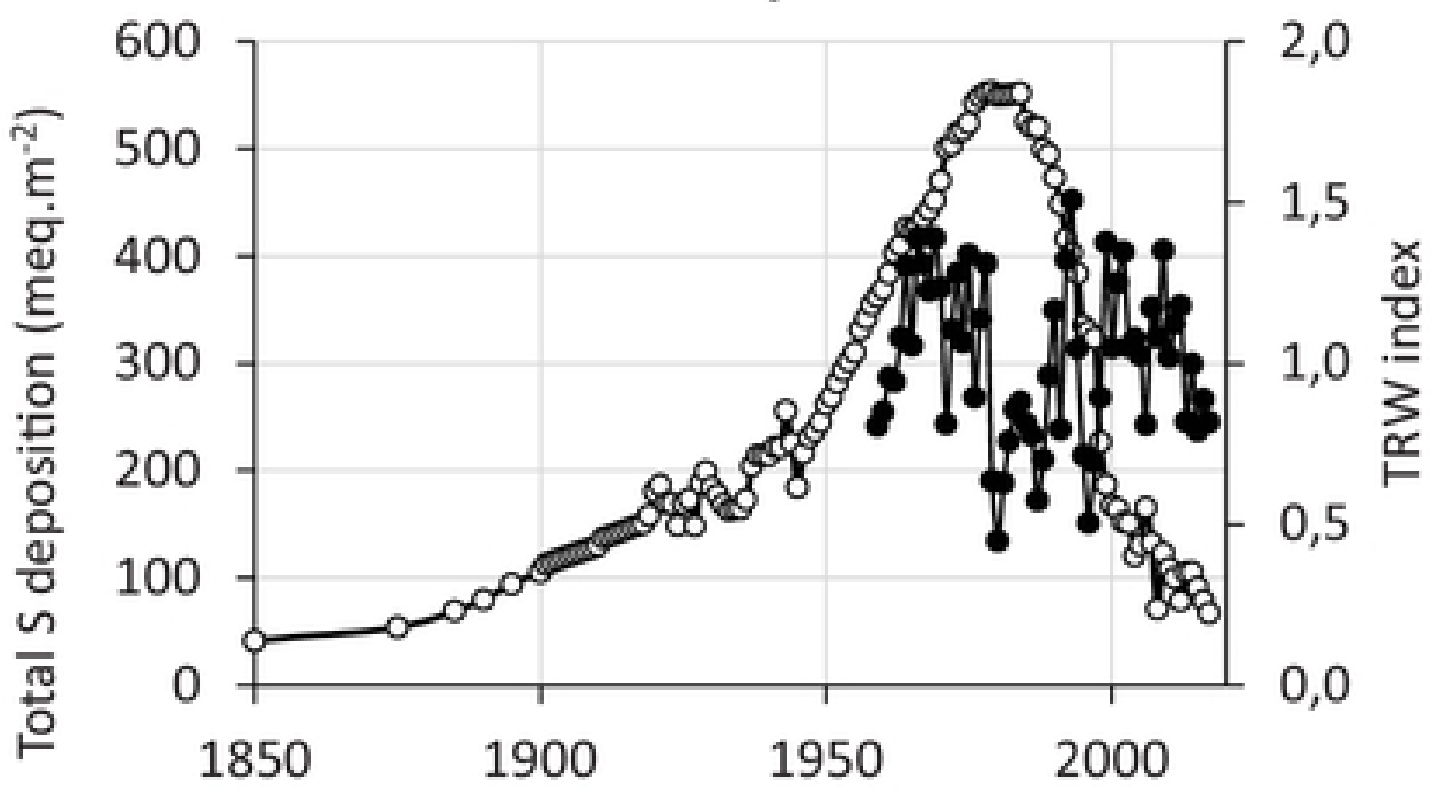

S1Annex FigureS1.3.1 